\title{
LA EDIFICACIÓN PÚBLICA DE LA MONARQUía NACIONAL. \\ CONTEXTOS, SIGNIFICADOS Y CEREMONIALES EN TORNO AL MONUMENTO A LA PATRIA ESPAÑOLA PERSONIFICADA EN EL REY ALFONSO XII (1886-1922)
}

\author{
THE PUBLIC CONSTRUCTION OF THE NATIONAL \\ MONARCHY. CONTEXTS, MEANINGS AND CEREMONIALS \\ AROUND THE MONUMENT TO THE SPANISH HOMELAND \\ PERSONIFIED IN THE KING ALFONSO XII (1886-1922) ${ }^{1}$
}

\author{
Rafael Fernández-Sirvent \\ Universidad de Alicante
}

\begin{abstract}
SUMARIO: I. INTRODUCCIÓN: EL SIGLO DEL ESTADO-NACIÓN, DE LA MONARQUÍA NACIONAL Y DE LOS GRANDES MONUMENTOS A LA PATRIA.- II. ORIGEN Y SIMBOLISMOS DEL MONUMENTO A ALFONSO XII EN EL RETIRO DE MADRID.- III. LA MONARQUÍA EN ESCENA: ALFONSO XIII Y LOS HITOS DEL MONUMENTO ERIGIDO EN MEMORIA DE SU PADRE Y A LA PATRIA/NACIÓN ESPAÑOLA (1902-1922).- IV. EPÍLOGO Y CONSIDERACIONES FINALES.- V. ILUSTRACIONES.- VI. BIBLIOGRAFÍA
\end{abstract}

Resumen: Desde un enfoque político-cultural, este texto presenta los principales hitos, significados y ceremoniales referidos al dilatado proceso de proyección y construcción material y simbólica del gran monumento conmemorativo, emblema por excelencia de reafirmación de la monarquia nacional durante la Restauración española, erigido en el parque de El Retiro de Madrid y dedicado "a la patria española personificada en el rey D. Alfonso XII". El estudio abarca el periodo 1886-1922. La puesta en escena de los actos oficiales fue presidida por Alfonso XIII de Borbón: colocación de la primera piedra (1902) e inauguración (1922).

\begin{abstract}
From a political-cultural approach, this text focuses on the main milestones, meanings and ceremonials referred to the extensive process of projection and material and symbolic construction of the great memorial, emblem par excellence of reaffirmation of the National Monarchy during the Spanish Restoration, erected in the park El Retiro in Madrid, and dedicated "to the Spanish Homeland personified in the King D. Alfonso XII". The study covers the period 1886-1922. The staging of official acts was presided by Alfonso XIII de Borbon: laying of the first stone (1902) and inauguration (1922).
\end{abstract}

1 Este artículo se enmarca en el proyecto de investigación "Las monarquías en Europa meridional (siglos XIX y XX). Culturas y prácticas de la realeza" (HAR2016-75954-P). Un primer esbozo de este trabajo se presentó, bajo el título "Monarquía nacional y espacio público. Análisis comparativo de la concepción política del Vittoriano de Roma y del monumento a Alfonso XII en E1 Retiro de Madrid", en el Convegno internazionale "Le monarchie dell'Europa meridionale e le sfide della modernità", celebrado en Nápoles entre el 15 y el 17 de noviembre de 2018. 
Palabras clave: Monumentos, memoria, monarquía nacional, Alfonso XII de Borbón, María Cristina de Habsburgo-Lorena, Alfonso XIII de Borbón.

Key Words: Monuments, memory, National Monarchy, Alfonso XII of Borbon, Maria Cristina de Habsburgo-Lorena, Alfonso XIII of Borbon.

\section{INTRODUCCIÓN: EL SIGLO DEL ESTADO-NACIÓN, DE LA MONARQUÍA NACIONAL Y DE LOS GRANDES MONUMENTOS A LA PATRIA}

Numerosas investigaciones historiográficas y de otras disciplinas sociales y técnicas - sobre todo en el ámbito de la arquitectura pública, el urbanismo y las artes plásticas - han puesto de relieve el alto poder nacionalizador que en la Edad Contemporánea tuvo la erección de monumentos conmemorativos en el espacio público, de forma muy especial durante la segunda mitad del Diecinueve y el primer cuarto del siglo XX. Esos decenios, caracterizados por una gran eclosión monumentalística, coinciden con un tiempo en que el control del espacio público urbano por parte de las élites sociales locales y de las autoridades politicas estatales se convirtió para estos en un asunto de primerísimo orden. La finalidad era manifiesta: imponer a la población una cultura nacional que contribuyese a una mayor cohesión social mediante la conservación o reafirmación del orden establecido. Dicho de otro modo, se trataba de edificar, en forma de sugerentes e inspiradores monumentos "perpetuos", las esencias de la patria, resaltando en ellos los principales ideales, simbolos y personajes que las élites liberales pretendian convertir en elementos definitorios e indisociables de las respectivas identidades nacionales europeas.

Durante la era de las grandes revoluciones liberales, en muchos países europeos la monarquía fue un agente indispensable en los discursos y estrategias nacionalizadores. El XIX fue el siglo del Estado nacional y, en consecuencia, el momento por excelencia de los monumentos nacionales. ${ }^{2}$ Lo fue en el viejo continente, pues el Estado-nación es una creación europea, ${ }^{3}$ pero también en América tras las guerras de independencia y el nacimiento de los nuevos Estados-nación iberoamericanos -en el hemisferio americano, al contrario de lo que sucedió en Europa, la mayoría de nuevos Estados se constituyeron en repúblicas, salvo muy contadas excepciones-. ${ }^{4}$ En este sentido, el "largo siglo XIX” (1789-1914) nos ofrece numerosos ejemplos de la camaleónica adaptación de las monarquías a las exigencias de la política moderna. La institución

\footnotetext{
2 Una categorización de estos monumentos públicos puede verse en: Nikolaus Pevsner, Historia de las tipologías arquitectónicas, Ed. Gustavo Gili, Barcelona, 1979, p. 11. Como ya apuntó Jesús Gutiérrez Burón (El monumento a Alfonso XII en el parque del Retiro, Madrid, 1998, pp. 5-6) , 1lama la atención que en una obra tan bien informada, como la citada de Pevsner, el monumento nacional erigido en Madrid a la memoria de Alfonso XII ni siquiera se mencione en el capítulo dedicado a monumentos nacionales y a los grandes hombres.

3 Dieter Langewiesche, La época del Estado-nación en Europa, traducción al castellano de Jesús Millán, Publicacions de la Universitat de València, Valencia, 2012, pp. 25-30.

4 Rodrigo Gutiérrez Viñuales, Monumento conmemorativo y espacio público en Iberoamérica, Cátedra, Madrid, 2004; Antonio Annino y Francisco-Xavier Guerra (coords.), Inventando la nación. Iberoamérica. Siglo XIX, Fondo de Cultura Económica, México, 2003; Ivana Frasquet y Andréa Sleiman (eds.), De las independencias iberoamericanas a los estados nacionales (1810-1850). 200 años de historia, Iberoamericana Vervuert, Madrid, 2009.
} 
monárquica, que con la lógica jurídico-política derivada de la revolución liberal del principio revolucionario de la soberanía nacional- se habría extinguido o, cuando menos, habría acabado desprovista de toda o gran parte de su autoridad, no solo logró sobrevivir a las distintas oleadas revolucionarias, sino que en muchos casos los titulares de la corona se convirtieron en un referente simbólico y aglutinador en el proceso de construcción de las identidades nacionales en lo que Dieter Langewiesche denomina la "época del Estado-nación en Europa". ${ }^{5}$

Autoridades académicas como Maurice Agulhon, Pierre Nora, George Mosse, Catherine Brice, Carlos Reyero, Stéphane Michonneau, Christian Demange e Ignacio Peiró, ${ }^{6}$ entre otras, han estudiado de forma prolija los nuevos espacios de sociabilidad, los lugares de la memoria y los ceremoniales a ellos asociados, con sus mitos, liturgias, cultos cívico-patrióticos y resignificaciones políticas para conmemorar la nación. Se trata de temas que, en muchos de los casos más paradigmáticos, tuvieron una imbricación directa, en el sentido de que las élites sociales y las autoridades políticas que impulsaron algunos de esos proyectos conmemorativos buscaron un lugar privilegiado y transitado por la ciudadanía para levantar los grandes monumentos patrióticos que perpetuaran en el imaginario colectivo aquellos actos que se consideraban relevantes en torno a los orígenes o a los principales actores que contribuyeron a la consolidación de los modernos Estados nacionales occidentales.

Estos monumentos públicos a caballo entre el Ochocientos y el Novecientos responden a una determinada sensibilidad e intencionalidad política, a una nueva estética y a una estrategia de interacción entre el Estado y la sociedad de masas. Son al mismo tiempo receptores y producto de toda una serie de imágenes del pasado — de la tradición - que se proyectan hacia el futuro - la modernidada las generaciones venideras y que, por tanto, contribuyen a generar una historia oficial de la construcción nacional y acaban conformando, desde arriba, un nuevo imaginario político. Las autoridades políticas hicieron, por tanto, un uso público de la historia a través del control de sus formas y espacios de representación, así como mediante la dotación interesada de significados en cada contexto.

\footnotetext{
5 Dieter Langewiesche, La época del Estado-nación en Europa, op. cit., pp. 120-124; Roberto L. Blanco Valdés, La construcción de la libertad. Apuntes para una historia del constitucionalismo europeo, Alianza Editorial, Madrid, 2010, p. 171; Joaquín Varela Suanzes-Carpegna, "Algunas reflexiones metodológicas sobre la Historia Constitucional”, Historia Constitucional, n 8, 2007 , pp. 418-419; Rafael Fernández-Sirvent, Las grandes revoluciones: independencia y libertad. Claves para una historia comparada, Paraninfo Universidad, Madrid, 2018, pp. 13-27. Para el caso español remitimos a: Jesús Millán y María Cruz Romeo, "Modelos de monarquía en el proceso de afirmación nacional de España, 1808-1923”, Diacronie. Studi de Storia Contemporanea, n 16, 4, 2013; Emilio La Parra (coord.), La imagen del poder. Reyes y regentes en la España del siglo XIX, Sintesis, Madrid, 2011.

6 Maurice Agulhon, Marianne au pouvoir. L’imagerie et la symbolique républicaines de 1880 à 1914, Flammarion, París, 1989; Pierre Nora, Présent, nation, mémoire, Gallimard, París, 2011; George L. Mosse, La nacionalización de las masas. Simbolismo politico y movimientos de masas en Alemania desde las Guerras Napoleónicas al Tercer Reich, Marcial Pons, Madrid, 2005; Catherine Brice, Monumentalité publique et politique à Rome. Le Vittoriano, École Française de Rome, Roma, 1998; Carlos Reyero, La escultura conmemorativa en España. La edad de oro del monumento público, 1820-1914, Cátedra, Madrid, 1999; Stéphane Michonneau, Barcelona: memòria $i$ identitat. Monuments, commemoracions i mites, Eumo Editorial, Vic, 2002; Christian Demange, El Dos de Mayo. Mito y fiesta nacional (1808-1958), Marcial Pons/Centro de Estudios Políticos y Constitucionales, Madrid, 2004; Ignacio Peiró Martín, En los altares de la patria. La construcción de la cultura nacional española, Akal, Madrid, 2017.
} 
En términos generales, en buena parte del mundo occidental podemos hablar de un verdadero proceso de monumentomanía o estatuomanía -así lo califican C. Brice e I. Peiró-. Contando con el precedente del arte efimero de los arcos de triunfo, las representaciones móviles y carrozas engalanadas con materiales perecederos, que abundaron en las conmemoraciones del primer liberalismo, a partir de la segunda mitad del siglo XIX la estatuaria y los grandes conjuntos arquitectónicos y grupos escultóricos realizados con materiales nobles e imperecederos, como el mármol y el bronce, se erigieron en un nuevo modelo o producto cultural para la edificación pública en su forma artística de los Estadosnación.

Atendamos a un dato significativo: en España, de los 255 monumentos públicos erigidos bajo patrocinio estatal y gracias al impulso de numerosas sociedades conmemorativas surgidas en muchas ciudades, 226 se construyeron o iniciaron en la época de la Restauración, concretamente entre 1875 y 1914. Es más, la mayor concentración se dio entre 1901 y 1914, tras la crisis derivada del desastre colonial de 1898 y coincidiendo con la llegada efectiva al trono de Alfonso XIII, en 1902. A comienzos del siglo XX se disparó, pues, la erección de monumentos urbanos de signo nacionalista y patriótico, que se extendieron por todo el país, pero de forma muy especial en las calles, plazas y jardines públicos de la capital política del Reino de España: Madrid. ${ }^{7}$

Algunos de esos monumentos conmemorativos, como lugares de memoria concebidos para perpetuar el recuerdo de personas, ideas e instituciones politicas, se instituyeron desde entonces en teatros al aire libre idóneos para escenificar ante el pueblo ese proceso simbiótico decimonónico de nacionalización y constitucionalización de la monarquía o, dicho al revés, de monarquización de la nación, germen de un nuevo producto cultural: la monarquía nacional.

Los casos alemán e italiano constituyen dos ejemplos paradigmáticos, aunque con un punto de partida diferente al caso español. Tras culminar sus respectivos procesos de unificación política, en ambos Estados se dedicaron numerosas estatuas y monumentos nacionales al emperador de Alemania, Guillermo I, y al monarca del nuevo Reino de Italia, Victor Manuel II de Saboya. La herencia artística de la antigua Roma quedó patente en esta época por la proliferación de representaciones de monarcas europeos, con aire marcial, siguiendo el patrón de las estatuas ecuestres - como se verá, ese fue el caso de la gran estatua ecuestre de Alfonso XII en Madrid-. Tras la muerte en 1888 del fundador del Imperio alemán, Guillermo I, se levantaron en pocos años más de 300 monumentos dedicados al monarca y a la idea imperial, de unidad nacional, a él vinculada. Uno de los más imponentes fuera del ámbito urbano, de los categorizados como "monumento nacional", fue el construido en lo alto de la montaña de Kyffhäuser (Turingia), proyectado en 1888 e inaugurado en $1896 .^{8}$

\footnotetext{
7 Ignacio Peiró Martín, En los altares de la patria. La construcción de la cultura nacional española, op. cit., pp. 208-212; Carlos Reyero, La escultura conmemorativa en España. La edad de oro del monumento público, 1820-1914, op. cit.; Carlos Serrano, El nacimiento de Carmen. Símbolos, mitos y nación, Taurus, Madrid, 1999, pp. 185-201. Uno de los más detallados estudios de las esculturas madrileñas en este período en: María del Socorro Salvador, La escultura monumental en Madrid: calles, plazas y jardines públicos (1875-1936), Editorial Alpuerto, Madrid, 1990.
}

8 Johannes Sträter, "El recuerdo histórico y la construcción de significados politicos. El monumento al emperador Guillermo en la montaña de Kyffhäuser", Historia y Politica, n 1 , 1999, p. 91. Otros dos monumentos destacables de finales de siglo son el del "Deutschen-Eck" (1888- 
En el caso italiano, al nacimiento del Reino de Italia en 1861 siguió un proceso de fabricación de "italianos", de construcción de una nueva identidad nacional, cosa que el movimiento cultural del Risorgimento ya había iniciado a principios del Ochocientos. ${ }^{9}$ Para ello, las nuevas autoridades liberales no escatimaron esfuerzos para enraizar la recién estrenada nacionalidad en el imaginario colectivo. Así, por toda la geografia italiana, en los espacios públicos más concurridos, se cambió el nomenclátor de las principales calles, plazas y vias, se levantaron centenares de estatuas y monumentos conmemorativos a los héroes, mártires y padres de la patria, así como lápidas que recuerdan el día en que determinada ciudad celebró el plebiscito de adhesión a la nueva Italia. En apenas veinte años se construyó un verdadero "panteón nacional". En ese contexto de fervor nacionalista, la monarquía saboyana, que lideró el proceso de unificación, se convirtió en uno de los más potentes factores de integración nacional, ya que el nuevo rey de todos los italianos, Victor Manuel II de Saboya el Padre della Patria-, jugó un papel mediador como elemento de conciliación política (mediación en el juego parlamentario y ministerial) y también de conciliación social (relación del rey con el pueblo). Para generalizar un sentimiento monárquico entre la población fue necesario recurrir a los instrumentos clásicos de todo proceso de construcción nacional (escuela, ejército, prensa, instrucción pública...) para insistir en la italianidad de la Casa de Saboya. ${ }^{10}$

La muerte del rey Víctor Manuel II, en 1878, acentuó la necesidad de edificar el gran monumento nacional que merecía. Fue entonces cuando, en 1880, se proyectó la construcción, en la histórica colina Capitolina de Roma, del Monumento Nazionale a Vittorio Emanuele II, también conocido como el Vittoriano a l'Altare della Patria. La idea de lo que dicho monumento debía representar quedó bien establecida en las diversas memorias y proyectos que se escribieron para el concurso público, debidamente publicitadas en la Gazetta Ufficiale: "L'Italia risorta decretava un monumento a quel Re magánimo che, incarnando la grande idea nazionale, seppe addurla da Novara a Porta Pia". Ese majestuoso monumento nacional en el centro urbano de la capital política del Reino de Italia, coronado con una grandiosa estatua ecuestre del Re Galantuomo, fue inaugurado en 1911, aunque sus trabajos no se culminaron hasta finales de los años veinte. ${ }^{11}$

1897), en Coblenza, y el de "Porta Westfalica" (1888-1896), en Minden. Los tres monumentos fueron obra del arquitecto Bruno Schmitz, autor del célebre monumento a "La batalla de las naciones" (Völkerschlacht), en Leipzig. Una gran estatua ecuestre erigida al káiser Guillermo en Berlín fue inaugurada en 1897. Véase también: Volker Sellin, "Monarchia e Nazione in Germania dal 1848 al 1914", Memoria e ricerca. Rivista di storia contemporanea, n 42, 2013, pp. 33-50.

9 Umberto Levra, Fare gli italiani. Memoria e celebrazione del Risorgimento, Comitato di Torino dell'Istituto per la storia del Risorgimento italiano, Torino, 1992.

10 Catherine Brice, Monarchie et identité nationale en Italie (1861-1900), Éditions de 1'École des hautes études en scieces sociales, París, 2010, pp. 7-11; Catherine Brice, "La monarchia e la nazionalizzazione degli italiani (1861-1900)", Memoria e ricerca. Rivista di storia contemporanea, $\mathrm{n}^{\mathrm{o}}$ 42, 2013, pp. 69-86.

11 Concorso pel monumento al Re Vittorio Emanuele II da erigirsi in Roma a norma del programa. Pubblicato nella Gazzetta Ufficiale del 23 e 27 Settembre 1880, Tipografia di Mario Armanni, Roma, 1881, p. 3; Progetto del monumento da erigersi in Roma al primo Re d'Italia Vittorio Emanuele II, Stabilimento di Giuseppe Civelli, Firenze, 1882, p. 1; Descrizione del concetto espresso nel bozzetto contrassegnato col motto una pagina di storia presentato a concorso per la erezione di un monumento alla gloriosa memoria del Re Vittorio Emanuele in Roma, Tipografia Barbèra, Roma, 1881. Véase al 
Este artículo pretende aportar un análisis contextual del origen y del proceso de construcción del más ostentoso conjunto arquitectónico y escultórico erigido en la capital española para perpetuar el recuerdo de uno de sus monarcas más populares, de los pocos que en la historia de España llegaron a gozar de una leyenda blanca: Alfonso XII de Borbón. Como se explicará, este rey proporcionó a su vez rostro humano a la patria española, encarnó a la nación, en un tiempo la época de la Restauración- en que la consolidación de la monarquía se solapó con varias crisis de notable magnitud. Una de ellas después la inesperada muerte, en 1885, del jovencísimo monarca Alfonso XII. Otra, con consecuencias de mucho mayor calado sociopolítico, tras el desastre colonial de 1898, que actuó como precipitante del verdadero arranque, con extrema urgencia y determinación, del gran proyecto monumental patriótico-nacional para Madrid.

Por otra parte, en el cambio de siglo, los discursos regeneracionistas hicieron de la institución monárquica y, en concreto, del rey Alfonso XIII de Borbón —el Regenerador, entre otros apodos- el motor para liderar esa regeneración sociopolitica y moral de España tras el Desastre del 98. ${ }^{12}$ Así, en el marco de lo que Jaan van Osta categoriza como "monarquías escénicas" (performing monarchies), ${ }^{13}$ entre 1870 y 1914 se desarrolló en buena parte de Europa una estrategia de identificación entre monarquía y nacionalismo, de nacionalización de la monarquía, para lo que se hizo uso de todo tipo de representaciones y de ceremoniales. Es más, considero que en muchos casos el nexo lógico que se mantuvo en el imaginario colectivo tuvo más amplio espectro: entre MonarquíaNación-Patria.

En el estudio de caso que aquí se presenta esta triada queda bien patente: el concepto de "patriotismo", ya destacado por Jean-Jacques Rousseau como la virtud por excelencia del buen ciudadano, cobró especial importancia en el lenguaje político y social desde la Revolución francesa de 1789. La patria podía ser, sin más, el lugar o país en que se había nacido, pero con la Revolución liberal sus significados se matizaron y multiplicaron, de modo que la "patria" podia ser entendida como sinónimo de "nación", pero en muchos casos también de "monarquía", tanto en su acepción más tradicional como en la nueva versión de

respecto las siguientes monografias dedicadas al Vittoriano: Bruno Tobia, L'Altare della Patria, Il Mulino, Bologna, 1998; y Catherine Brice, Monumentalité publique et politique à Rome. Le Vittoriano, op. cit.

12 Javier Moreno Luzón, "Alfonso el Regenerador. Monarquía escénica e imaginario nacionalista, en perspectiva comparada (1902-1913)", Hispania, $\mathrm{n}^{\circ}$ 244, 2013, pp. 319-348; Javier Moreno Luzón, “¿El rey de todos los españoles? Monarquía y nación”, en Javier Moreno Luzón y Xosé M. Núñez Seixas (eds.), Ser españoles. Imaginarios nacionalistas en el siglo XX, RBA, Barcelona, 2013; Javier Moreno Luzón, "Monarchia in scena e discorsi nazionalisti nella Spagna del Rigenerazionismo (1902-1913)", Memoria e ricerca. Rivista di storia contemporanea, $\mathrm{n}^{\circ}$ 42, 2013, pp. 87-106; Morgan C. Hall, "El rey imaginado: la construcción política de la imagen de Alfonso XIIP", en Javier Moreno Luzón (coord.), Alfonso XIII. Un político en el trono, Marcial Pons, Madrid, 2003, pp. 59-82; Jesús Millán y Maria Cruz Romeo, "Modelos de monarquía en el proceso de afirmación nacional de España, 1808-1923”, op. cit., pp. 1-3.

13 Jaan van Osta, "The Emperor's New Clothes. The Reappearance of the Performing Monarchy in Europe, c. 1870-1914", en Jeroen Deploige y Gita Deneckere (eds.), Mystifying the Monarch. Studies on Discourse, Power, and History, Amsterdam University Press, Amsterdam, 2006, pp. 181-192. 
monarquía constitucional. ${ }^{14}$ La proyección de esa sutil correspondencia del elitista y vaporoso mundo de las ideas al imaginario colectivo popular fue de vital importancia en los procesos de construcción o de reafirmación de los Estados nacionales.

\section{ORIGEN Y SIMBOLISMOS DEL MONUMENTO A ALFONSO XII EN EL RETIRO DE MADRID}

En España, al igual que sucedió en países como Inglaterra, ${ }^{15}$ el proceso de formación de una identidad nacional giró históricamente en torno a la monarquía. Como se ha dicho, en la afirmación del Estado de derecho y la construcción de una nueva cultura politica liberal, el/la titular de la Corona jugó un papel esencial como simbolo de referencia e identidad colectiva.

Este proceso se magnifica todavía más si centramos el foco de atención en la época de la Restauración (monárquica y dinástica), que se inicia con la coronación de Alfonso XII de Borbón en 1875. El antecedente del Sexenio Democrático (1868-1874), con las experiencias de la monarquía "electa" de Amadeo I de Saboya (1871-1873) y la Primera República (1873-1874), sirvió de acicate para amplios sectores sociales, ya que en ese complejo marco donde imperó la inestabilidad política, los conflictos bélicos y la confrontación social, buena parte de las élites consiguieron llegar a un minimo consenso acerca del modelo de Estado (monárquico) que España necesitaba para la estabilidad y la modernización del país. Tras la coexistencia a lo largo del Diecinueve de varios modelos o nociones de monarquía, la Restauración supuso, entre otras cosas, la reafirmación de un modelo de monarquía liberal. ${ }^{16}$ Los artífices del nuevo régimen restauracionista, eso sí, blindaron a la institución monárquica, la dotaron de numerosas prerrogativas políticas y amplificaron, más si cabe, su poder simbólico. La monarquía se convirtió en la columna que vertebraba todo el sistema político y fue utilizada por sus numerosos afectos como un dispositivo de cohesión social de primer orden.

Cuando este pilar estuvo a punto de quebrarse, debido a la incertidumbre que generó la inesperada enfermedad y muerte del joven Alfonso XII (25-111885), Antonio Cánovas y Práxedes M. Sagasta, líderes de los dos grandes partidos dinásticos, alcanzaron un acuerdo - el Pacto de El Pardo- con el fin de evitar una crisis institucional que podía haber acarreado graves consecuencias para la estabilidad del régimen. En ese contexto en que el Partido Conservador de Cánovas cedió el Gobierno al Partido Liberal de Sagasta, institucionalizando así el bipartidismo o "turno de partidos", se inició una importante campaña propagandística con la finalidad de reforzar la imagen de la institución monárquica. La viuda del monarca, la desde entonces regente María Cristina de Habsburgo-Lorena (1885-1902), fue objeto de una intensa campaña publicística

14 Sobre los usos y semánticas del concepto "patria”, véase: Javier Fernández Sebastián y Juan Francisco Fuentes Aragonés (dirs.), Diccionario politico y social del siglo XIX español, Alianza Editorial, Madrid, 2002, pp. 512-523. Evidentemente, esta correlación también tuvo su versión en los Estados nacionales no monárquicos, en este caso entre República-Nación-Patria.

15 Andrzej Olechnowicz, "I Regno Unito e la sua monarchia (1837-1914)", Memoria e ricerca. Rivista di storia contemporanea, $\mathrm{n}^{\circ}$ 42, 2013, pp. 15-50.

16 Jesús Millán y María Cruz Romeo, “Modelos de monarquía en el proceso de afirmación nacional de España, 1808-1923”, op. cit., pp. 9-15 y 18. 
en la que se la representaba, esencialmente, como el nexo de unión entre los reinados de su esposo Alfonso XII y del hijo póstumo de este, el futuro Alfonso XIII (Ilustración 1). ${ }^{17}$ Los promotores de esa campaña se sirvieron de la popularidad de que gozaba el difunto rey para forjar en el imaginario colectivo una leyenda blanca en torno a Alfonso XII, el Pacificador - y, por extensión, a lo que significó su reinado para una "vuelta a la normalidad"-, cosa que no fue dificil puesto que buena parte de ese trabajo ya se había realizado con cierto éxito durante su breve reinado. ${ }^{18}$

Fue en ese momento cuando urgió la necesidad de construir un monumento en memoria de Alfonso XII. En 1886, el senador José Polo de Bernabé sería el primer politico en solicitar al Gobierno el alzamiento de un monumento al monarca difunto. Al año siguiente, el senador presentó un proyecto de ley donde propuso erigir una estatua ecuestre al rey Alfonso XII "para que su nombre se transmita de generación en generación por medio de obras de arte en mármoles y bronces". El artículo 1 de la ley decretaba lo siguiente: "En nombre de la nación española, se erigirá una estatua ecuestre de bronce al inolvidable y malogrado Monarca Don Alfonso XII, delante del Palacio Real y centro de la plaza llamada de la Armería, o donde designe su Augusta Viuda, S. M. Doña María Cristina, Regente del Reino". ${ }^{19}$

En los detalles de la exposición del proyecto se ofrecía, además, una síntesis de las virtudes del monarca, que la nación jamás debería dejar morir en su memoria. Una comisión del Congreso de los diputados, presidida por Antonio Cánovas del Castillo, aprobó el proyecto de ley, que también llegó a recibir la sanción de la reina regente. Desde este momento y hasta 1901 la ley quedó archivada por múltiples motivos. Algunos medios, como el periódico $A B C$, achacaron el retraso de su ejecución a las dificultades de consolidación del régimen debido, sobre todo, a las guerras coloniales. ${ }^{20}$ En la memoria final redactada por la Junta del Monumento también se citaban los terribles efectos socioeconómicos derivados de la Primera Guerra Mundial. ${ }^{21}$ El revulsivo nacional que supuso el desastre colonial de 1898 volvió a poner de actualidad la imperiosa necesidad de levantar un monumento nacional en memoria del monarca, con el cual se pretendia reforzar la legitimidad de la Corona mediante la glorificación del rey en quien se había materializado la restauración de la monarquía, resaltando en él, sobre todo, los valores de paz y estabilidad - recordemos la caracterización

17 Sobre la imagen pública de la regente María Cristina, véase: Mónica Moreno Seco, "María Cristina de Habsburgo, la (in)discreta regente”, en Emilio La Parra (coord.), La imagen del poder. Reyes y regentes en la España del siglo XIX, Síntesis, Madrid, 2011, pp. 389-430.

18 Sobre las representaciones e imágenes simbólicas de este monarca, véase: Rafael FernándezSirvent, "Alfonso XII, el rey del orden y la concordia", en Emilio La Parra (coord.), La imagen del poder. Reyes y regentes en la España del siglo XIX, op. cit., pp. 335-388; Rafael Fernández-Sirvent, "De Rey soldado a Pacificador. Representaciones simbólicas de Alfonso XII de Borbón”, Historia Constitucional, $\mathrm{n}^{\circ} 11,2010$, pp. 47-75.

19 Monumento a S. M. el Rey Don Alfonso XII. Memoria, 1901-1922, Imprenta de Ramona Velasco, Madrid, 1922, p. 5.

20 Los detalles de la tramitación y exposición de este proyecto de ley y la referencia del periódico ABC (4-VI-1922), en: Jesús Gutiérrez Burón, El monumento de Alfonso XII en el parque del Retiro, op. cit., pp. 8-10.

21 Monumento a S. M. el Rey Don Alfonso XII. Memoria, 1901-1922, op. cit., pp. 18-19. 
de Alfonso XII como el Pacificador-, piedra angular del discurso político y también monumental de la Restauración.

La idea inicial era que el monumento estuviese terminado con motivo de la celebración de la mayoría de edad de Alfonso XIII, pero la realidad fue bien distinta. El proyecto no se retomaria hasta 1901, precisamente el momento en que se acercaba la mayoría de edad del rey. Fue entonces cuando, con extrema urgencia y mediante Real Decreto, se nombró una Junta, presidida por el diputado y ex ministro Francisco Romero y Robledo, con el fin de emprender todos los trámites y trabajos necesarios para procurar que la inauguración del monumento pudiera coincidir, a poco más de un año vista, con las festividades en honor a la entronización de Alfonso XIII.

El primer acuerdo de la Junta fue realizar el encargo de la estatua ecuestre al prestigioso escultor Mariano Benlliure. Las bases del concurso público para la adjudicación del resto de trabajos se publicaron en la Gaceta de Madrid (17-41901). Dos meses después, de los diecinueve anteproyectos presentados (Ilustración 2), el jurado falló otorgar el primer premio al del arquitecto José Grases i Riera. ${ }^{22}$ La decisión no careció de intenso debate y a punto estuvo de declararse desierto, pues ningún proyecto contó con demasiados apoyos. Si la propuesta presentada por José Grases bajo el lema "María Cristina" prosperó se debió a dos razones. La primera, porque Romero Robledo, presidente de la Junta, pensó que era el proyecto más idóneo para poder reunir al mayor número de artistas y de ese modo mostrar los progresos que la escultura había conseguido alcanzar durante la Restauración, pues el arquitecto no entraba en disquisiciones artístico-escultóricas. La segunda razón, y clave en el asunto, fue porque el anteproyecto de J. Grases era el único en satisfacer de forma resuelta uno de los principales problemas en torno al monumento: su emplazamiento. ${ }^{23}$

Al carecer Madrid de una altura propicia sobre la que elevar el monumento - Grases ponía como ejemplos la Acrópolis de Atenas, Montmartre en París o el Kremlin en Moscú-, para que este se convirtiera en un verdadero lugar de peregrinaje, local y turístico, como referente de afirmación nacional, el tema de la ubicación sería crucial para el empeño. Por supuesto, la plaza de la Armería del Palacio Real no era, ni mucho menos, el sitio más idóneo, dadas las restricciones generales de acceso a la mayor parte de la población. Era necesario encontrar un lugar más público que favoreciese el contacto con el pueblo. El arquitecto José Grases i Riera pensó que dadas las dimensiones del monumento, se requería de un espacio muy amplio para su emplazamiento, cual era la práctica habitual en las grandes capitales europeas y americanas, que levantaban las estatuas a sus grandes personajes en los mejores parques. Por ello, el Parque de Madrid o Retiro era el lugar escogido por esta y por otras razones estéticas y simbólicas que acaba exponiendo. En resumen, el entorno natural, con una verde arboleda de fondo, en el margen del estanque grande del parque, daría la sensación de que el monumento se sumergiese, mediante una suave escalinata en forma de abanico, en el agua y se vería reflejado ante los numerosos viandantes que por allí solían

22 José Grases i Riera, Memoria del anteproyecto de monumento que ha de erigirse en Madrid a la gloria del Rey Don Alfonso XII, el Pacificador. Lema "Maria Cristina”, M. Romero impresor, Madrid, 1901.

23 Monumento a S. M. el Rey Don Alfonso XII. Memoria, 1901-1922, op. cit., pp. 13-14. 
transitar, lo cual daría una mayor percepción espacial y constituiría un espectáculo estético sublime para los sentidos:

“(...) la erección de esta obra grandiosa no ha de costar ni un solo árbol

(...) Por la parte del agua, el monumento avanzará su plataforma general

y sus grandes pilarotes de los extremos de la columnata hacia la margen

del estanque, y alli desplegará valientemente sobre las aguas sus

balcones, antepechos, balaustradas y graderias, cortadas a trechos por

peanas con leones de bronce, hasta sumergir su basamento por debajo de la superficie liquida”.

Además del escaso impacto medioambiental, el monumento enriquecería el parque de El Retiro, tan escaso por entonces de obras arquitectónicoescultóricas. Por otra parte, el emplazamiento contaba con el simbolismo de establecerse sobre un antiguo Sitio Real fundado por Felipe II y engrandecido por Felipe IV, donde se celebraron fiestas y ceremoniales de toda indole, donde se reunieron las Cortes hasta 1789 y en el lugar donde vivieron en su palacio real Felipe IV, Felipe V, Fernando VI y Carlos III. Este último monarca fue quien permitió la entrada pública para el esparcimiento de madrileños y visitantes. Ese simbolismo se completaba por la vecindad de la basílica de Atocha, donde el homenajeado Alfonso XII celebró sus dos bodas, además de por el hecho de que la calle más amplia junto al parque llevaba el mismo nombre del monarca. También quedaba muy próxima a la iglesia de San Jerónimo, creada por Fernando e Isabel, los Reyes Católicos, fundadores de la Monarquía española. ${ }^{24}$

Tras ganar el concurso, el arquitecto Grases reconocía en una detallada memoria que su proyecto estaba inspirado en varios modelos extranjeros, y entre ellos destacaba los monumentos levantados en Alemania a Guillermo I, el erigido al príncipe Alberto en un parque londinense y los dedicados a Pedro el Grande en San Petersburgo y a Víctor Manuel II en Italia. Señalaba Grases que "la nación española tiene ya un nuevo timbre para figurar con más derecho que antes en el concierto de las naciones civilizadas, al levantar, por primera vez en su suelo, un monumento a la Patria, personificada en el egregio Rey D. Alfonso XII el Pacificador". ${ }^{25}$

Es más, la idea de Grases era realizar una obra grandiosa y original en la España del momento, que exaltara los valores del régimen, y por ello argumentaba la elección del monarca Alfonso XII, por representar una síntesis humana e institucional, un referente nacional, de las cualidades politicas y morales que se pretendía transmitir a las próximas generaciones:

“(..) representará también a la Patria, personificada en el Rey constitucional de los tiempos modernos, que no fue Rey de ningún partido y que lo fue de todos los españoles; que advino al poder como la única esperanza de paz, de orden y de libertad, y que estuvo a la altura de su

\footnotetext{
24 José Grases i Riera, Memoria del anteproyecto de monumento que ha de erigirse en Madrid a la gloria del Rey Don Alfonso XII, el Pacificador. Lema "María Cristina”, op. cit., pp. 7-11. Para más detalles sobre los distintos grupos y elementos que componen el monumento, remitimos a María del Socorro Salvador, La escultura monumental en Madrid: calles, plazas y jardines públicos (18751936), op. cit., pp. 355-381.

25 José Grases i Riera, Memoria del monumento que se erige en Madrid a la Patria española personificada en el rey Don Alfonso XII, M. Romero impresor, Madrid, 1902, pp. 5-6.
} 
tiempo, y aun lo sobrepujó en su pais como hombre de alta cultura, tolerante, liberal, demócrata y hasta orador de fácil palabra; héroe de la caridad (...) militar esforzado y valiente.

Pero la caracteristica de su reinado, y este aspecto ha de reflejarse en el monumento, fue la gloria de haber terminado la guerra civil peninsular y las insurrecciones ultramarinas (...) La historia ha asignado ya a este preclaro Rey el dictado de Pacificador".

Para reforzar esa idea, el monumento sería coronado en su punto más alto en expresión del elevado sentimiento patriótico que sustentaba la obra - con una estatua ecuestre del insigne escultor Mariano Benlliure en la que quedaria materializada para la posteridad, en bronce, esa idea de paz, esperanza y prosperidad. La gran escultura, de unos 6 metros de altura, representaba al rey, espada en mano con un porte apaciguado que da la sensación de rechazar hacia atrás (producto, pues, del pasado) los actos bélicos y, posiblemente, el recuerdo de los recientes desastres políticos y militares del país. Por otra parte, su gesto y su mirada se dirigen al horizonte, al porvenir, que podia representar para el país el reinado de su hijo el rey Alfonso XIII (Ilustración 8). ${ }^{26}$ En la parte baja del frente principal sobre el que se eleva la estatua ecuestre, se leeria la dedicatoria "A la gloria de Alfonso XII el Pacificador", que en su ejecución final acabó en "A S. M. D. Alfonso XII el Pacificador”. En los ángulos del mismo se colocarían los escudos de las Órdenes militares de Santiago, Montesa, Calatrava y Alcántara, en la cara anterior el Toisón de Oro y en la posterior el gran collar de Carlos III. En definitiva, "insignias y atributos, unas y otros, que forman el emblema nobilisimo de la Monarquía española”. En las plataformas superiores de este segundo cuerpo se levantarian cuatro grupos escultóricos que simbolizarian la Paz, la Patria, la Libertad y el Progreso.

Alrededor de la parte central, rodeando y arropando la estatua ecuestre del monarca, se abriría una doble columnata en forma de hemiciclo que representaría a la Patria o a la Nación española -en la memoria definitiva se prefiere aludir a la nación, en lugar de a la patria de la que se hablaba en el anteproyecto presentado a concurso-, 27 con sus 49 provincias, cuyos escudos se dispondrían en sus cornisas sobre los ejes de las columnas, alternando con las siglas "A. XII", que evocaban al monarca y, por ende, a la "monarquía nacional", que se reafirmó durante su reinado, o al menos ese era el mensaje que se pretendía transmitir (Ilustraciones 11 y 12).

\section{LA MONARQUÍA EN ESCENA: ALFONSO XIII Y LOS HITOS DEL MONUMENTO ERIGIDO EN MEMORIA DE SU PADRE Y A LA PATRIA/NACIÓN ESPAÑOLA (1902-1922)}

"En el día 17 de Mayo de 1902 se proclamará y coronará como Rey de España en ejercicio a S. M. El Rey Don Alfonso XIII, en cuanto cumpla los dieciséis años de edad.

26 Carlos Serrano, El nacimiento de Carmen. Símbolos, mitos y nación, op. cit., pp. 197-198.

27 José Grases i Riera, Memoria del anteproyecto de monumento que ha de erigirse en Madrid a la gloria del Rey Don Alfonso XII, el Pacificador. Lema "María Cristina”, op. cit., p. 13; José Grases i Riera, Memoria del monumento que se erige en Madrid a la Patria española personificada en el rey Don Alfonso XII, op. cit., p. 8. 
Entre los festejos y ceremonias con que se ha de celebrar tan fausto acontecimiento, no podrá haber ninguno tan patriótico, tan elevado, tan politico y educativo, y en que se logre hermanar a la corte con el pueblo, el ejército y las clases todas de la sociedad, como el de que el primer acto público del adolescente Monarca, inmediatamente después de su proclamación sea su traslación, entre el séquito y la corte, tropas extendidas en la carrera y aclamaciones de la multitud, desde la Residencia Real hasta el sitio que en lo sucesivo se denominará más propiamente Real del Retiro, para que coloque la primera piedra del monumento que se levantará a la memoria de su padre, el Rey D. Alfonso XII el Pacificador".28

De este modo cerraba el arquitecto José Grases su memoria del anteproyecto del monumento, anticipando lo que en realidad sucedió un año después. El 17 de mayo de 1902, Alfonso XIII cumplió dieciséis y tuvo lugar la solemne ceremonia de su coronación. Durante varios dias se alternaron diversos actos institucionales con todo tipo de festejos y celebraciones populares.

Concedida por el Ayuntamiento de Madrid la preceptiva autorización para construir el monumento, el lugar que entonces ocupaba el embarcadero del estanque grande del Retiro, se dispuso que la colocación de la primera piedra coincidiera con la jura del rey Alfonso XIII, programándose dicho acto para el día después de la misma, el 18 de mayo.

En el marco de las festividades reales, la concurrida ceremonia de colocación de la primera piedra estuvo presidida por el recién coronado Alfonso XIII. La familia real estuvo acompañada de los miembros del Gobierno, de un nutrido grupo de parlamentarios y representantes de la altas jerarquías militar y eclesiástica, así como de un buen número de aristócratas y de autoridades políticas y varios príncipes y enviados extranjeros invitados a los actos de la coronación. El nuncio del Papa, monseñor Rinaldini, auxiliado por el obispo de Madrid-Alcalá y otros representantes del alto clero, procedió a la bendición de la primera piedra en el momento previo a su colocación. Como se puede apreciar en las fotografias que recuerdan el acto, muchas de ellas circuladas durante los meses posteriores mediante postales, cientos de personas anónimas se acercaron a curiosear alrededor del estaque y algunos incluso dentro, remando en pequeñas embarcaciones (Ilustraciones 4, 5 y 6).

A continuación, antes de dejar descender la piedra y de que el joven monarca echara una paleta de cemento, de forma simbólica, se depositó en el hoyo excavado una caja que contenía el acta que se redactó para dar fe del histórico acontecimiento. En ella se leía lo siguiente:

“Comisión ejecutiva del monumento a Alfonso XII:

Cumpliendo acuerdos anteriores, y previa aceptación de S. M. el Rey Don Alfonso XIII de poner la primera piedra en el Monumento que, por ley hecha en Cortes y por suscripción nacional, se ha erigido a la memoria de S. M. el Rey Don Alfonso XII, se constituyó la Junta en el Parque de Madrid a las cuatro y media de la tarde del día 18 de mayo del corriente año [1902].

28 José Grases i Riera, Memoria del anteproyecto de monumento que ha de erigirse en Madrid a la gloria del Rey Don Alfonso XII, el Pacificador. Lema "María Cristina", op. cit., pp. 18-19. 
Presentes S. M. el Rey, su Augusta Madre Doña María Cristina, sus hermanos, SS. AA. RR. los Principes de Asturias, Doña Maria Teresa, Doña Isabel y Doña Eulalia; los Principes, Enviados extraordinarios, Embajadores y Ministros que en representación de las naciones amigas vinieron a enaltecer con su presencia el advenimiento al Trono de Su Majestad; el Ministerio responsable, toda la alta servidumbre de los Reyes, las Mesas de los Cuerpos colegisladores, los altos dignatarios de Estado y las Autoridades civiles, militares y eclesiásticas que lo son en la actualidad, se procedió por el señor nuncio de Su Santidad, monseñor Rinaldini, asistido por el obispo de Madrid-Alcalá y del alto clero, a la bendición de la primera piedra.

Acto seguido, S. M. el Rey Don Alfonso XIII y S. M. la Reina Madre, ex Regente del Reino, Doña María Cristina, tiraron de los cordones preparados al efecto y dejaron caer sobre la base aquella primera piedra del Monumento que se va a levantar en perpetua memoria de los hechos $y$ virtudes de S. M. Don Alfonso XII.

Y para que conste, los individuos de la Junta firman esta acta, que quedará en copia bajo los cimientos de esta obra, como testimonio de amor y de la admiración que los españoles contemporáneos conservaron al recuerdo del Rey Don Alfonso, a quien denominaron El Pacificador.

Parque de Madrid, 18 de mayo de 1902. El presidente, Francisco Romero y Robledo. El secretario, Marqués de Valdeiglesias."29

Las obras comenzaron con cierta diligencia gracias a las 900.000 pesetas que inicialmente se recaudaron mediante suscripción nacional. También hubo algunas aportaciones anuales del Congreso y el Senado, aunque hay que decir que estas fueron intermitentes, y otras muy decisivas como los kilos de bronce que el ministerio de la Guerra cedió, mediante ley, a la Comisión ejecutiva del Monumento. ${ }^{30}$ La parte arquitectónica avanzó bastante rápido y en tres años estuvo casi concluida. No obstante, el arquitecto Grases se quejaba de la insuficiencia de los recursos públicos, ya que un monumento nacional de esas dimensiones y características patrióticas debía ser costeado fundamentalmente por el Estado, como así sucedía en otras capitales europeas. Al hacer recuento de los recursos económicos que hicieron posible la consecución del conjunto arquitectónico-escultórico en 1922, la Junta quiso destacar los esfuerzos del Ejército y de las grandezas y títulos del Reino, que sufragaron gran parte de los gastos de la estatua ecuestre del rey y del grupo escultórico La paz, así como del Banco de España la Compañia Arrendataria de Tabacos, el Ayuntamiento de Madrid y la Diputación provincial de Barcelona, entre otros. Pero sobre todo se destaca que para la terminación de las obras del monumento fue decisiva la aportación anual, entre 1907 y 1920, de 75.000 pesetas del Congreso y del Senado, con cargo a sus presupuestos. ${ }^{31}$ Como se ha dicho, la parte

29 Monumento a S. M. el Rey Don Alfonso XII. Memoria, 1901-1922, op. cit., pp. 14-15.

30 Expediente relativo al proyecto de ley cediendo la cantidad de bronce necesaria con destino al monumento a Alfonso XII. Archivo del Senado, leg. 969, $\mathrm{n}^{\circ}$ 9. Y Diario de las sesiones de Cortes. Senado, apéndice $1^{\circ}$ al $n^{\circ}$ 49. Cit. en Jesús Gutiérrez Burón, El monumento de Alfonso XII en el parque del Retiro, op. cit., pp. 43 y 57.

31 Monumento a S. M. el Rey Don Alfonso XII. Memoria, 1901-1922, op. cit., pp. 21-23. 
arquitectónica quedó prácticamente concluida en 1905. En 1909 tuvo lugar la colocación de la grandiosa estatua ecuestre del rey Alfonso XII, obra de Mariano Benlliure, a quien se puede ver en una fotografia guiando los minuciosos trabajos de colocación (Ilustraciones 7 y 8).

Finalmente, el 3 de julio de 1922, aun a falta de algunos elementos por rematar, se celebró la gran ceremonia de Estado que daba por inaugurado de forma oficial el gran monumento nacional de España. En el Archivo General de Palacio de Madrid se conservan algunas fotografias donde se puede observar el gran despliegue escénico del histórico momento (Ilustraciones 9 y 10). En este caso, predominó una puesta en escena con aire muy castrense: un desfile militar alrededor del hemiciclo que rodeaba el gran pedestal central donde se eleva la estatua ecuestre de Alfonso XII y varios discursos en la base de la misma, sobre la escalinata, con Alfonso XIII presidiendo el acto rodeado de buena parte de su Estado mayor, de algunas autoridades políticas y junto a su esposa, Victoria Eugenia de Battenberg, y su madre, María Cristina de Habsburgo. A esas alturas, después de la Primera Guerra Mundial, el nacionalismo regeneracionista y liberal del que dio muestras el monarca hasta 1914, había transitado hacia una versión más marcadamente nacionalcatólica y militarista, donde el Ejército y lo castrense iba ganando cada vez mayor espacio en todas las esferas de la sociedad. Podemos decir que siguió la estela o caracterización de rey soldado de su padre Alfonso XII y apuntaló, más si cabe, esa imagen de rey muy apegado a la institución militar, a su Estado mayor y a las costumbres castrenses. ${ }^{32}$ Tanto fue así que el rey que dio un notable impulso al proceso de nacionalización de la monarquía, en 1923 apoyó el golpe de Estado liderado por Miguel Primo de Rivera y el Ejército, que produjo una ruptura con el régimen constitucional restauracionista y dio paso a una dictadura.

\section{EPÍLOGO Y CONSIDERACIONES FINALES}

El monumento del parque madrileño no fue el único que se dedicó a Alfonso XII. Durante la Restauración, se levantaron estatuas en recuerdo del monarca en plazas públicas de poblaciones como el Real Sitito de Aranjuez o la Alhama de Granada. De construcción más reciente, hoy se puede contemplar una estatua de bronce de Alfonso XII, de cuerpo entero, en el llamado Balcón de Europa de Nerja (Málaga). Se trata de poblaciones que recibieron la visita y atenciones del rey después de catástrofes epidémicas (cólera) o naturales (inundaciones y terremotos).

Mención destacada merece otro monumento dedicado a la restauración de la monarquía que llegó a ser construido (y al poco destruido) en Sagunto (Valencia), lugar donde se inició el pronunciamiento militar del general Arsenio Martínez Campos que precipitó la restauración de Alfonso XII de Borbón en el trono español. La idea de este monumento saguntino surgió muy pronto, en 1876, pero por distintas razones no se materializaría hasta casi medio siglo después. En la inauguración oficial, el 3 de junio de 1927, estuvo también presente Alfonso XIII,

32 Jesús Millán y María Cruz Romeo, "Modelos de monarquía en el proceso de afirmación nacional de España, 1808-1923”, op. cit., pp. 2-3; Rafael Fernández-Sirvent, "De Rey soldado a Pacificador. Representaciones simbólicas de Alfonso XII de Borbón”, op. cit., pp. 47-75; Carolyn P. Boyd, "El rey-soldado. Alfonso XIII y el ejército", en Javier Moreno Luzón (ed.), Alfonso XIII. Un politico en el trono, Marcial Pons, Madrid, 2003, pp. 213-237. 
en un acto con una comitiva muy variopinta, donde esta vez el protagonismo se repartió entre el monarca Borbón, el alcalde de Valencia, marqués de Sotelo, y el dictador Miguel Primo de Rivera. Tampoco faltó la bendición del monumento por el arzobispo de Valencia, auxiliado por el arcipreste de Sagunto. Según las crónicas de aquella jornada de júbilo para los valencianos y para la nación española, los dos primeros dieron un discurso, pero Alfonso XIII no pronunció ni una palabra. Este monumento, que se concibió como un homenaje a la restauración de la monarquía y fue construido en piedra con el propósito de perdurar décadas o siglos, resultó ser de lo más efímero (Ilustración 13). No habían transcurrido ni cuatro años cuando en abril de 1931, con el advenimiento de la Segunda República, el monumento fue objeto de la "fiesta revolucionariorepublicana" y del fervor iconoclasta ejercido contra los símbolos monárquicos que sacudió el país, en ocasiones auspiciado por las nuevas autoridades republicanas. ${ }^{33}$ En un primer momento, se destruyeron diversos emblemas monárquicos, como la corona real o el toisón de oro, con la intención de conservar la estructura y reconvertirlo en un monumento en memoria de la República. Finalmente, como sucedió con otros tantos monumentos durante la Guerra Civil, fue demolido por completo. Algunas cabezas de león que decoraban ese monumento a la Restauración se conservaron mucho tiempo emplazadas en la Glorieta de Sagunto. Más recientemente fueron trasladadas a unos parterres del jardin que se halla a los pies del teatro romano de Sagunto. ${ }^{34}$ Visto este ejemplo, resulta extraño que el monumento madrileño del Buen Retiro consiguiera salir incólume -desconozco la razón- de los generalizados, y muchas veces incontrolados, ataques "monarcofóbicos".

A modo de conclusión podemos decir que, después de una cierta actividad monumentalística durante el reinado de Isabel II, la época de la Restauración acabó con la magra política monumentalística de los años inmediatamente precedentes del Sexenio Democrático (1868-1874). ${ }^{35}$ Fue a partir de entonces cuando el espacio público urbano se repobló con la mayor parte de los inspiradores monumentos conmemorativos que hoy podemos contemplar, en su mayoría, por todo el país y también en territorios de ultramar de antigua soberanía española.

33 Remitimos al artículo sobre esta temática que forma parte de este dossier monográfico: Marie-Angèle Orobon y José Luis González Fernández, "Echar a la calle: el destronamiento simbólico de Alfonso XIII", Historia Constitucional, $\mathrm{n}^{\circ}$ 20, 2019. Sobre iconoclasia, resultan de especial interés: Dario Gamboni, La destrucción del arte. Iconoclasia y vandalismo desde la Revolución Francesa, Cátedra, Madrid, 2014; también la sugerente introducción de Emmanuel Fureix y el preámbulo de Bertrand Tillier, La mort des statues. Imaginaires archä̈ques et usages politiques de l'iconoclasme", en Emmanuel Fureix (dir.), Iconoclasme et révolutions. De 1789 à nos jours, Éditions Champ Vallon, Ceyzérieu, 2014. La introducción de E. Fureix está disponible en linea (ver bibliografia).

34 Manuel Girona Rubio, "El monumento de Sagunto a la Restauración de la monarquía borbónica", Braçal, $\mathrm{n}^{\circ}$ 37, 2008, pp. 81-110. Sobre el último emplazamiento de los leones del monumento: http://castillodesagunto.blogspot.com/2013/12/el-sagunto-que-ya-no-existe-1el.html

35 Sobre la simbología politica revolucionaria tras la Revolución española de 1868 y acerca de la escasa iniciativa monumentalística de este periodo, véase: Marie-Angèle Orobon, "La carne de la politica: ruptura democrática y simbología", Ayer. Revista de Historia Contemporánea, n 112 , 2018, pp. 73-98. 
En el contexto europeo de construcción o reafirmación de los Estadosnación, las políticas de memoria para conmemorar de forma "perpetua" los hechos o personajes más destacados en ese proceso de construcción nacional adoptó en casi todas las grandes ciudades forma de monumento y, sobre todo en las grandes capitales estatales, de macroproyectos monumentales de exaltación nacional. El caso del Vittoriano o Altare della Patria de Roma, que sirvió de inspiración al monumento nacional madrileño que aquí se estudia, es uno de sus ejemplos más palmarios y mejor estudiados.

El monumento a la patria española personificada en el rey Alfonso XII, el Pacificador, es un reflejo fidedigno del entramado político y cultural de una época, el resultado de una manifiesta preocupación de las élites del momento por preservar y exaltar la institución monárquica como dispositivo de cohesión nacional y como elemento de primer orden en el juego político del sistema restauracionista. Los ceremoniales públicos y, en general, la puesta en escena de la "monarquía nacional", encarnada en el caso aquí estudiado en Alfonso XIII de Borbón, es otra muestra más de la creciente importancia que la imagen pública de los reyes y las reinas adquirirá en la época de consolidación de la política moderna y de la sociedad de masas.

\section{ILUSTRACIONES}




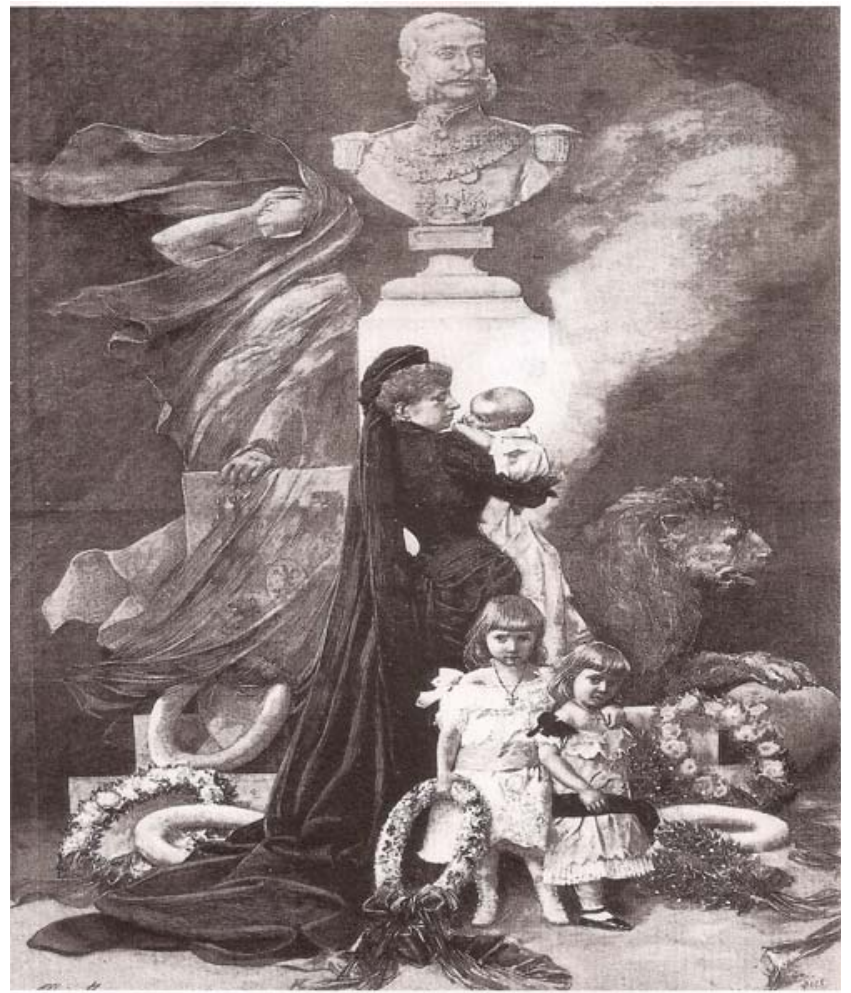

Ilustración 1. La regente María Cristina ofrece el bebé (Alfonso XIII) a una efigie de su padre, rodeada de sus hijas, que sostienen una corona fúnebre. Se representa a la viuda regente como nexo entre los reinados de Alfonso XII y Alfonso XIII. Grabado publicado en La Ilustración Española y Americana, 22-11-1886.

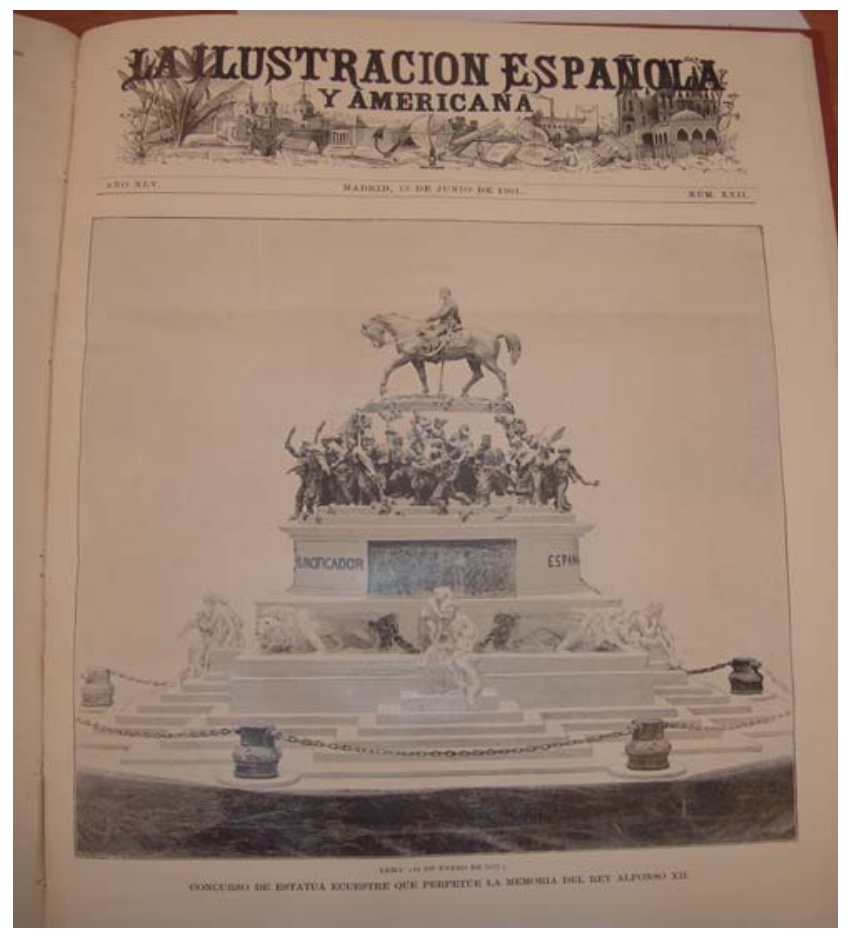

Ilustración 2. Uno de los proyectos (no el ganador) presentado al concurso público para erigir un monumento a Alfonso XII. Publicado en la portada de La Ilustración Española y Americana, 15-61901. 


\section{Rafael Fernández-Sirvent}

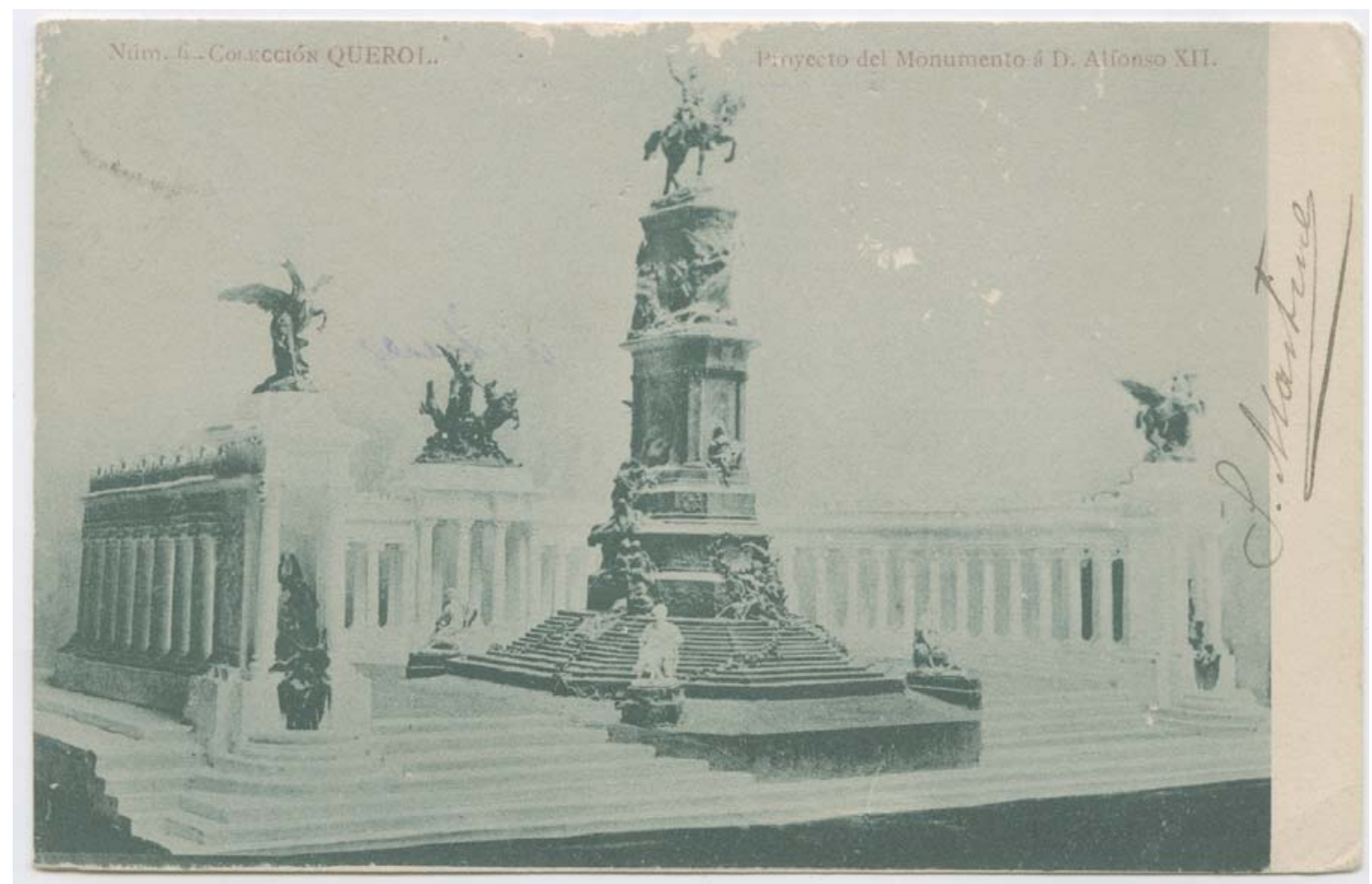

Ilustración 3. Postal con la imagen el proyecto del Monumento a Alfonso XII. 1901. En Biblioteca Digital memoriademadrid.

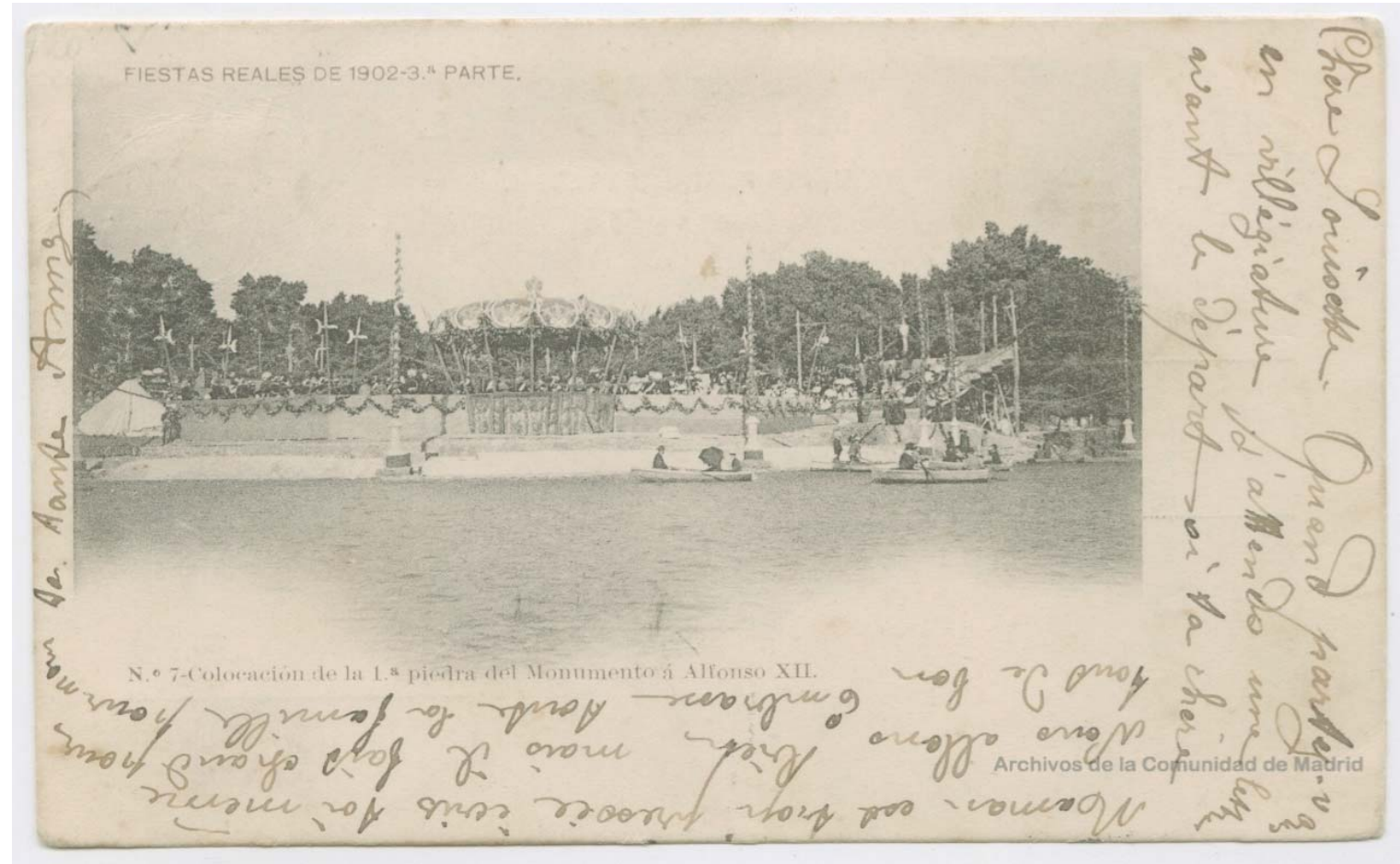

Ilustración 4. Postal circulada con foto de las fiestas reales en la zona del estanque del Retiro en honor a la coronación de Alfonso XIII. Mayo de 1902. En Biblioteca Digital memoriademadrid. 


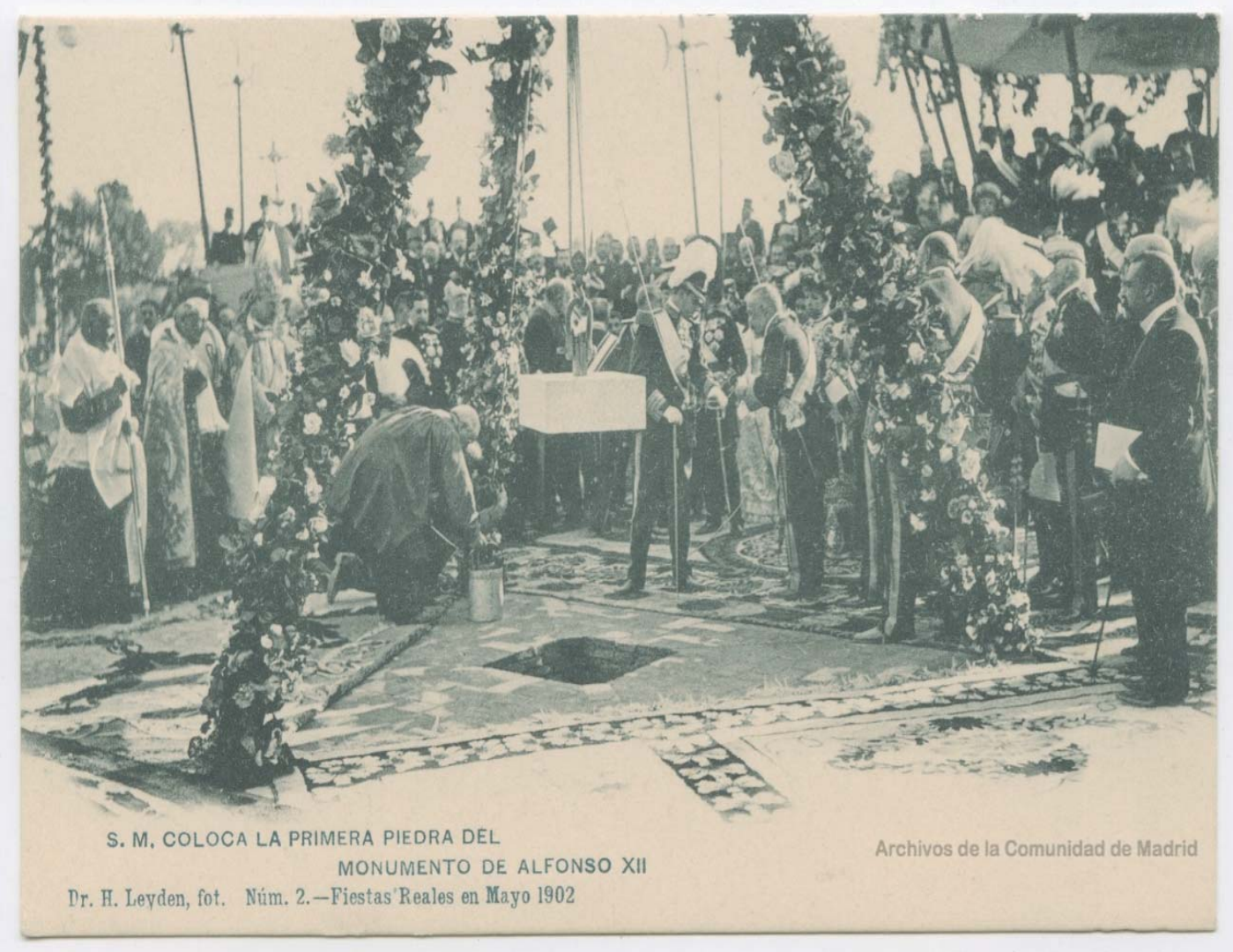

Ilustración 5. Postal con foto de la colocación de la primera piedra del Monumento a Alfonso XII, el día después de la coronación de Alfonso XIII. Mayo de 1902. En Biblioteca Digital memoriademadrid.

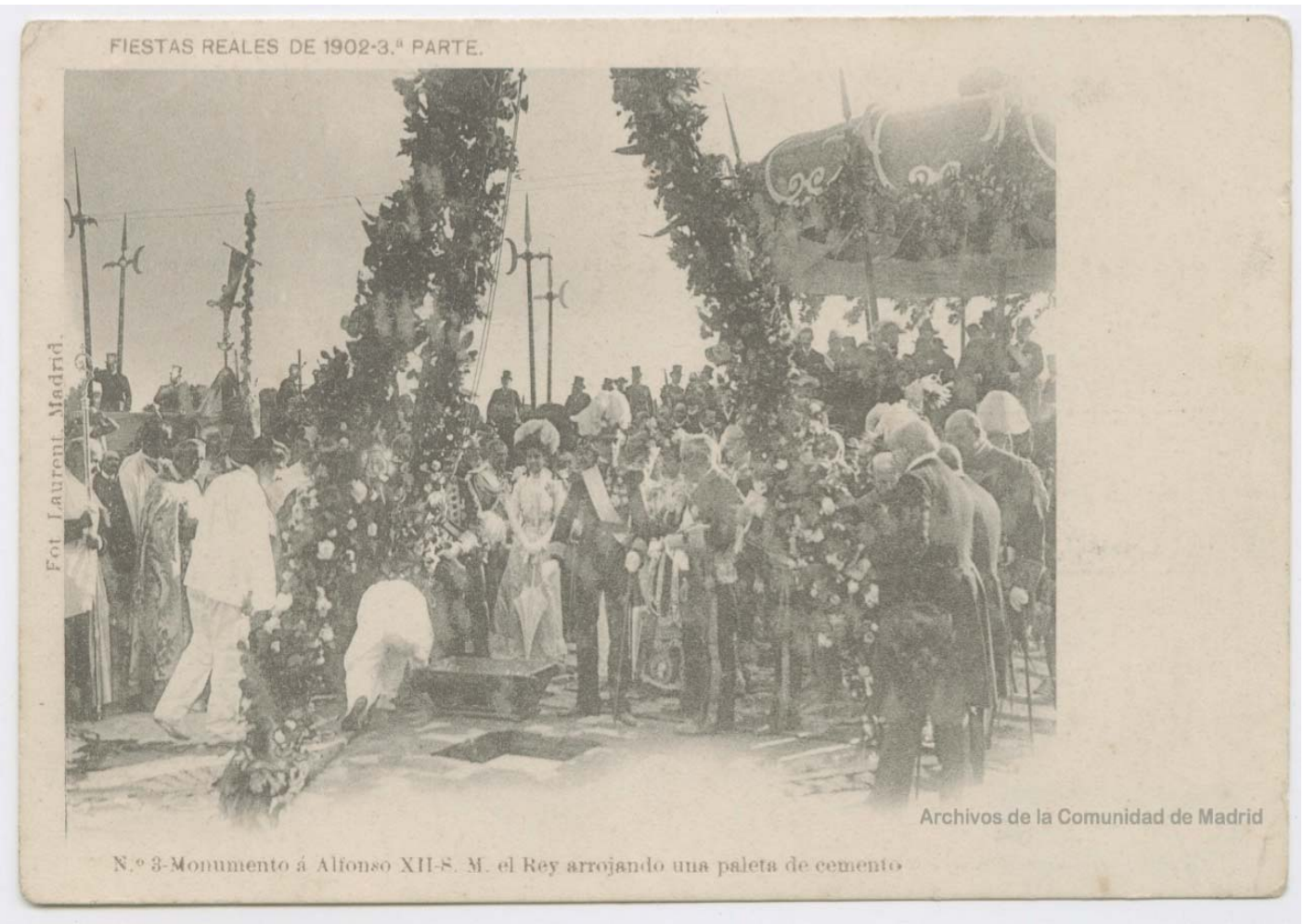

Ilustración 6. Postal con foto de Alfonso XIII echando la primera paleta de cemento sobre la primera piedra del Monumento en honor a su padre. Mayo de 1902. En Biblioteca Digital memoriademadrid. 


\section{Rafael Fernández-Sirvent}

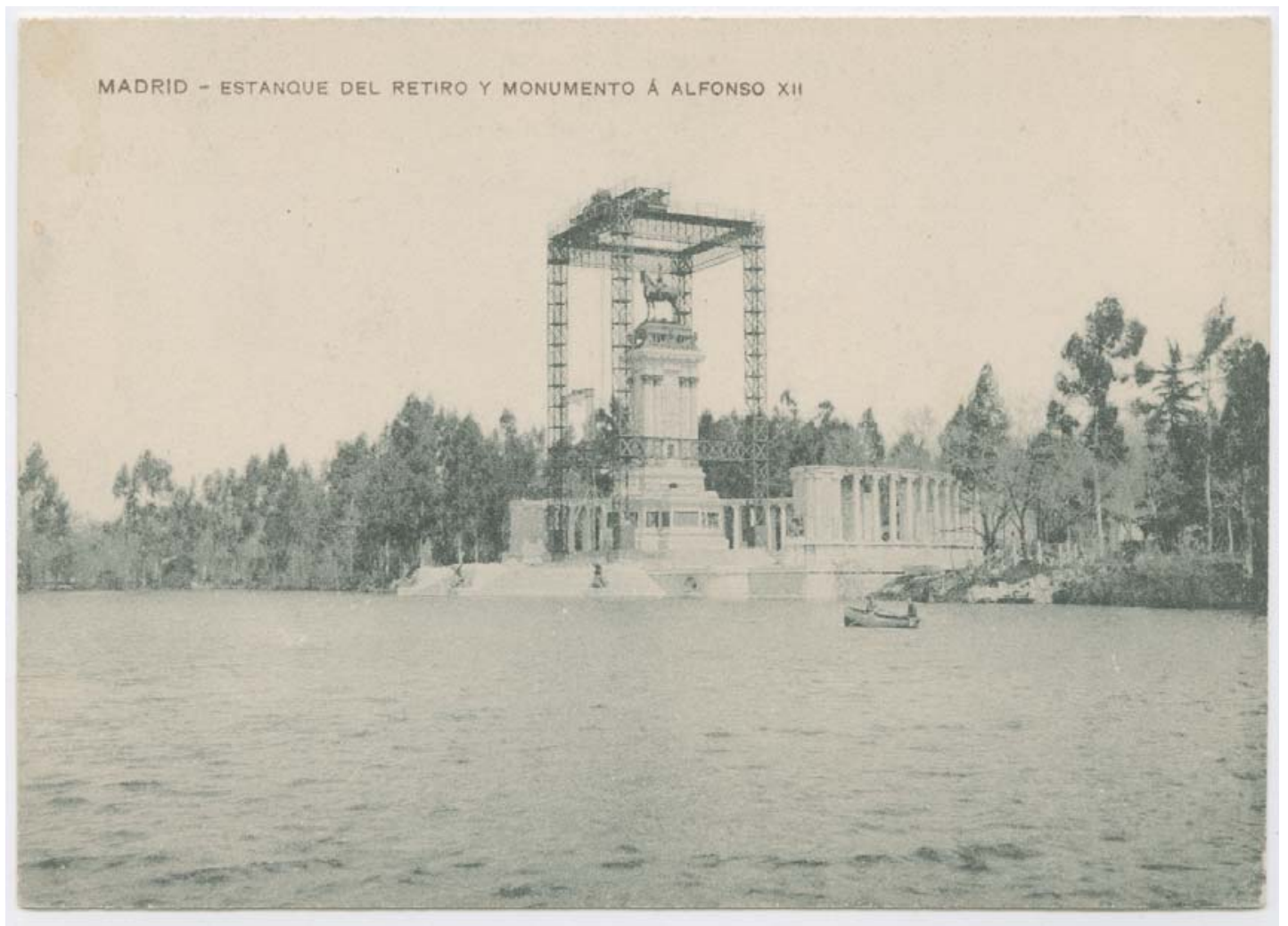

Ilustración 7. Postal con foto de la terminación de la parte arquitectónica (escalinata en abanico y hemiciclo columnario) y de la colocación de la estatua ecuestre. 1909. En Biblioteca Digital memoriademadrid.

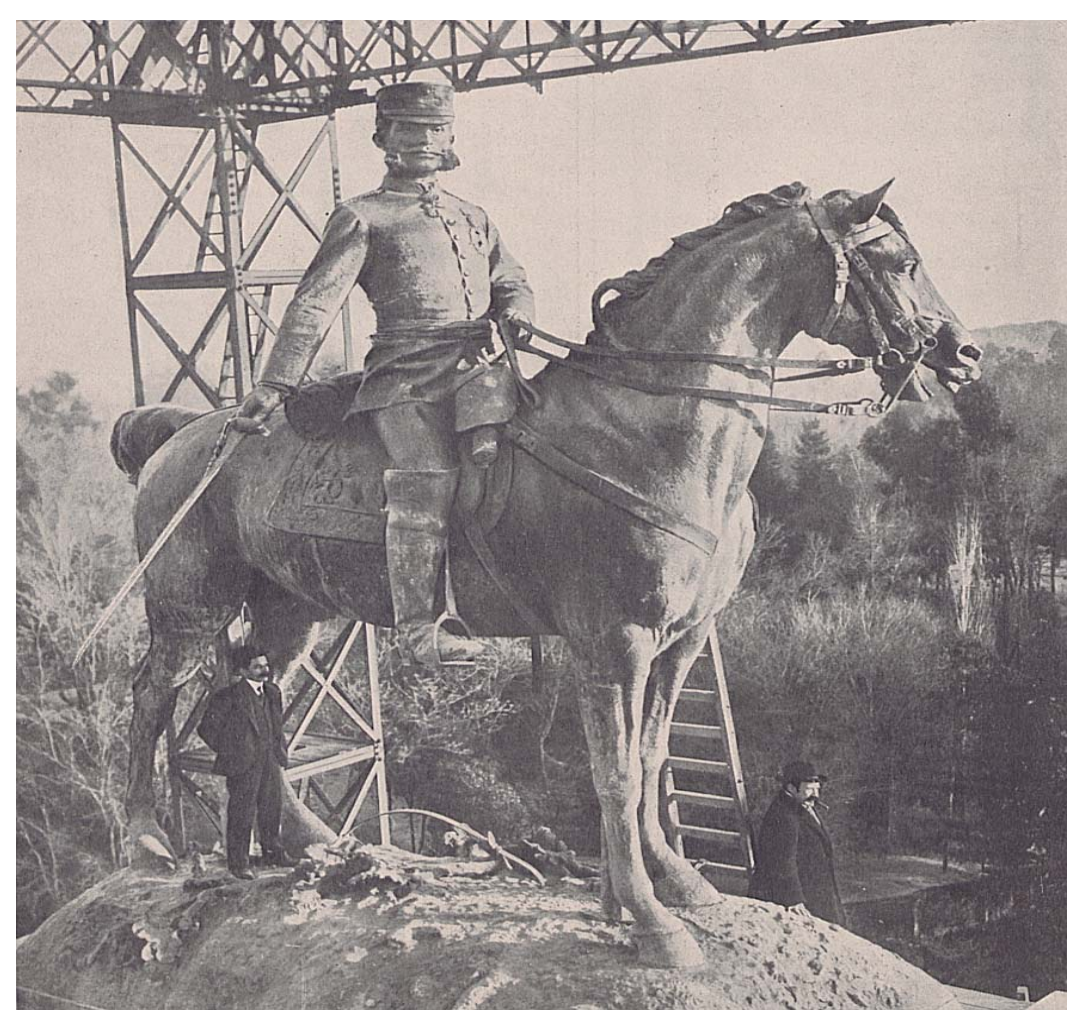

Ilustración 8. Foto de Mariano Benlliure supervisando los detalles de colocación de la estatua ecuestre de Alfonso XII, de unos 6 metros de altura. 1909. En Biblioteca Digital memoriademadrid. 


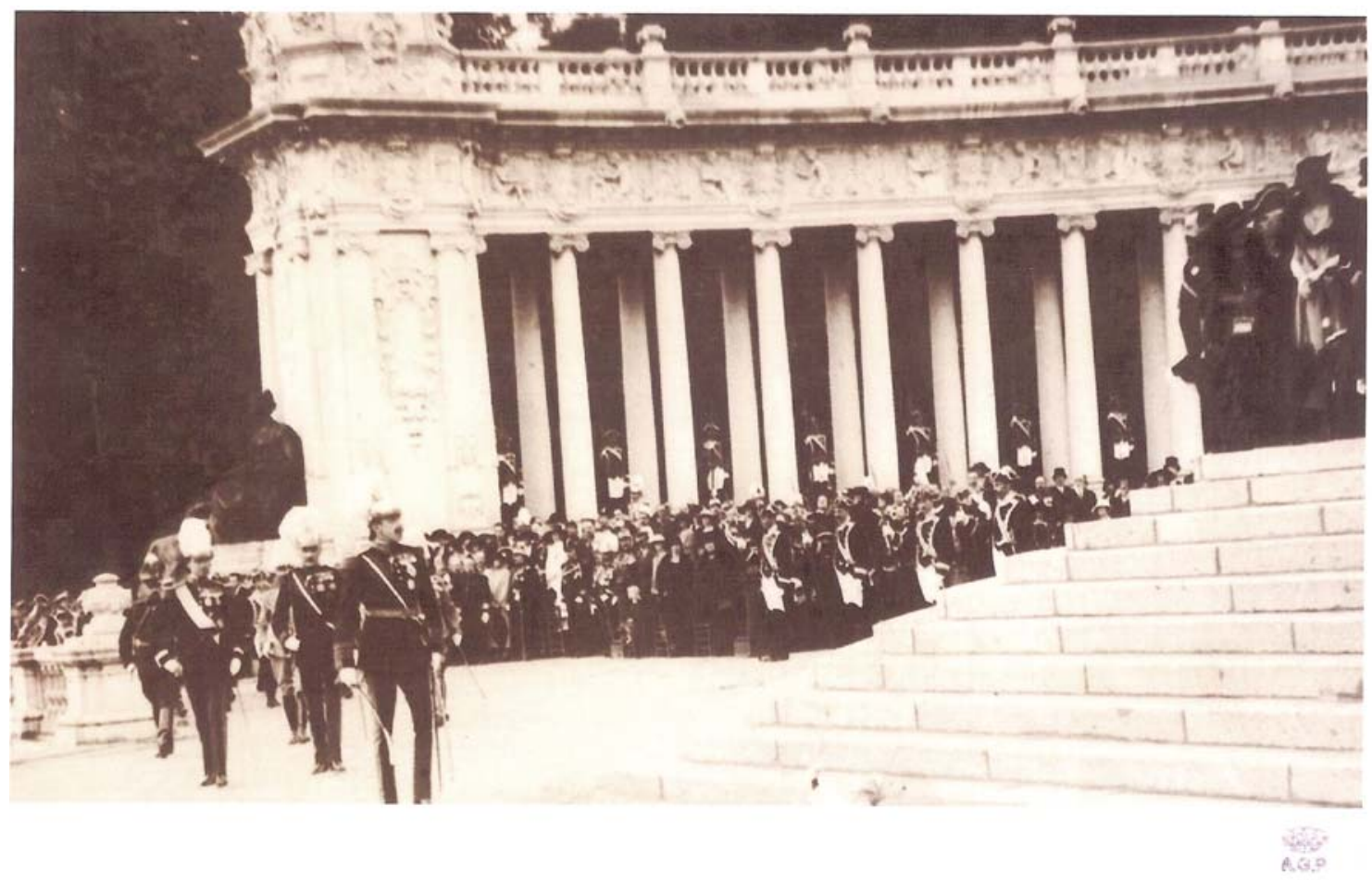

Ilustración 9. Ceremonia de inauguración oficial del Monumento a Alfonso XII. Presidida por Alfonso XIII. 3 de julio de 1922 . Archivo General de Palacio (Madrid), nº 10166563.

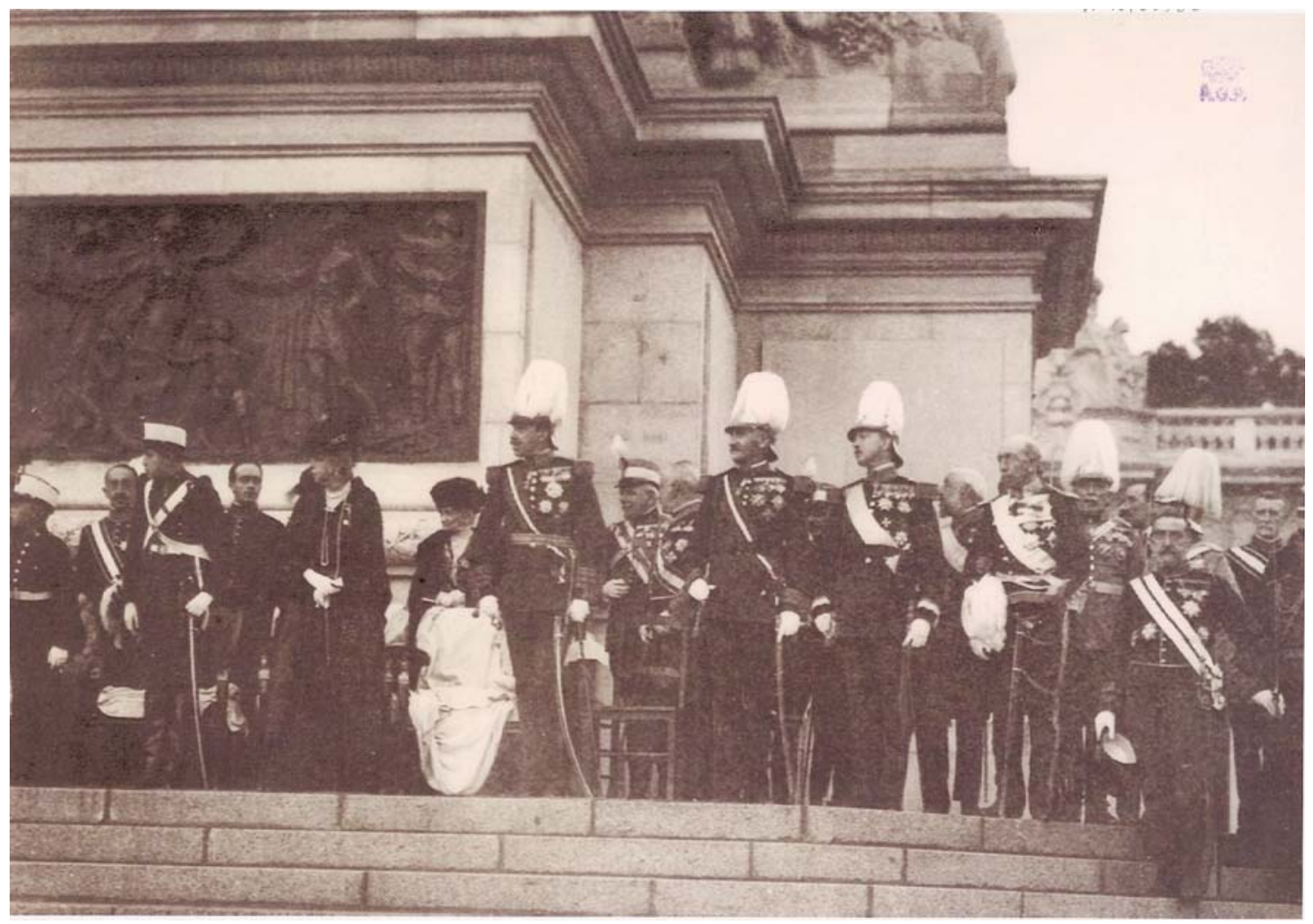

Ilustración 10. Ceremonia de inauguración oficial del Monumento a Alfonso XII. Con Alfonso XIII, su esposa Ena de Battenberg, la ex regente María Cristina de Habsburgo, la plana mayor del Ejército y otras autoridades políticas. 3 de julio de 1922 . Archivo General de Palacio (Madrid), $n^{\circ}$ 10166566. 


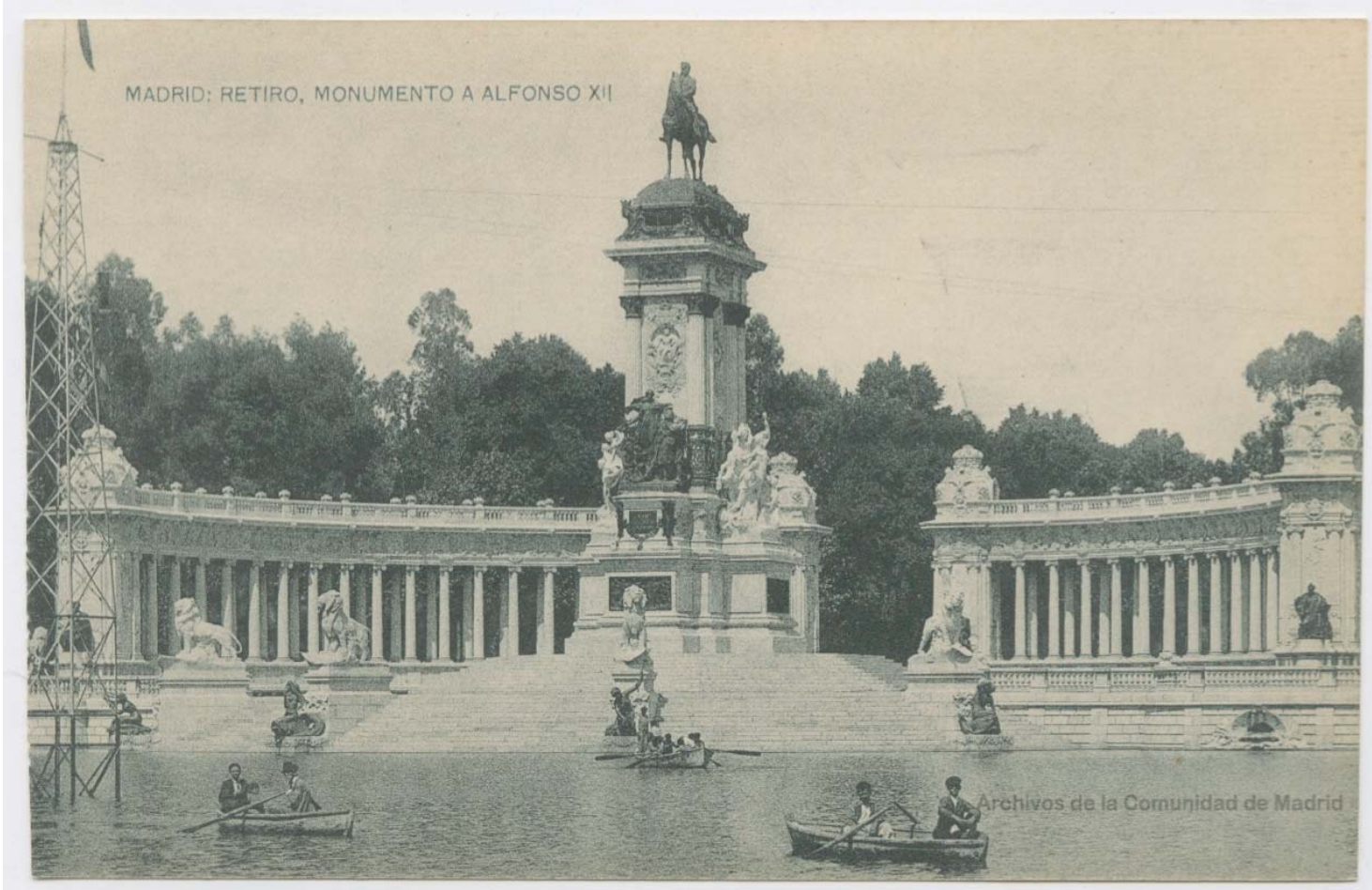

Ilustración 11. Postal con foto del Monumento a Alfonso XII tras su inauguración. En Biblioteca Digital memoriademadrid.

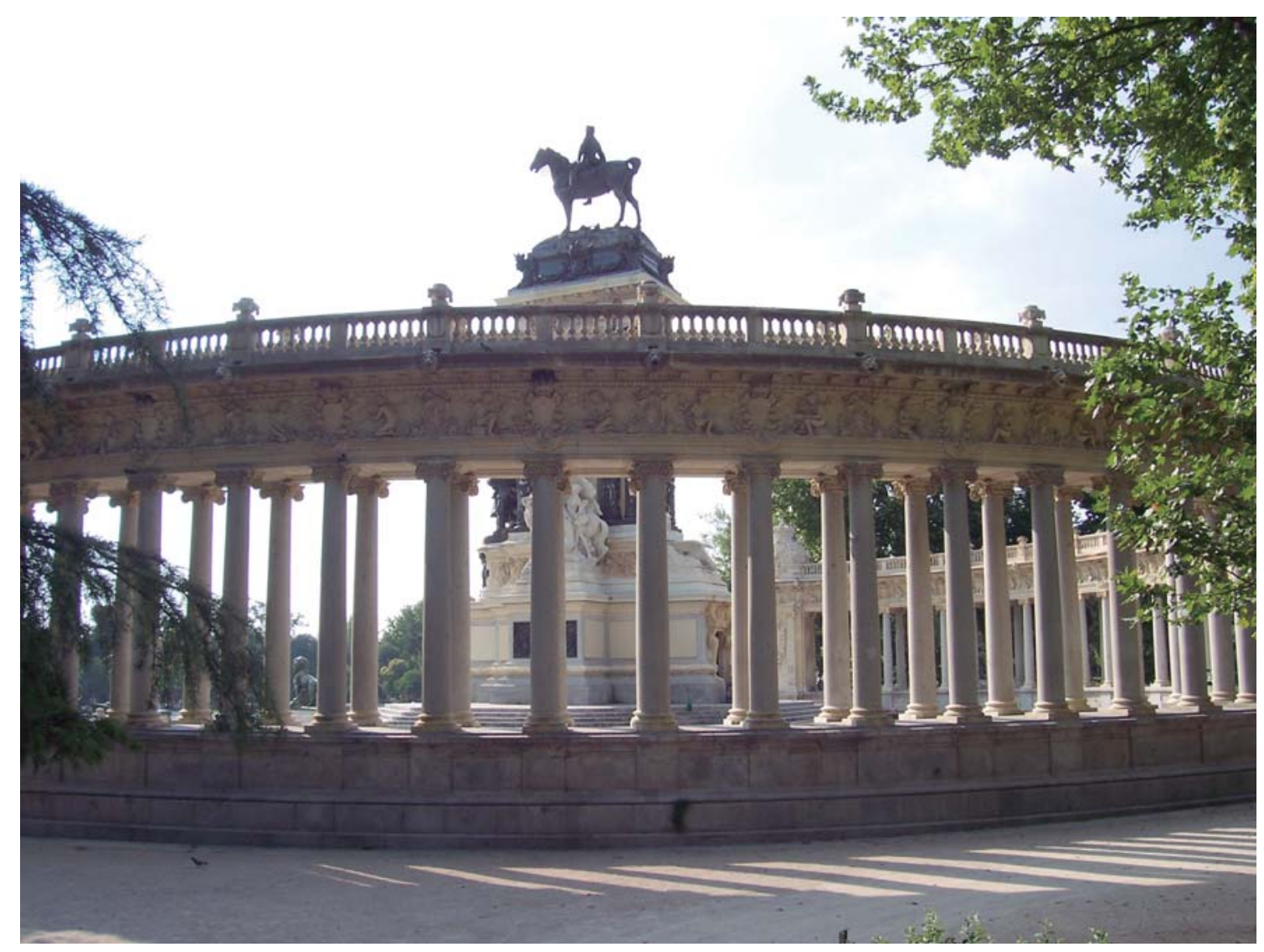

Ilustración 12. Detalle del hemiciclo con doble columnata, representación de las 49 provincias españolas, envolviendo, de forma simbólica, a la monarquía nacional. Foto del autor. 


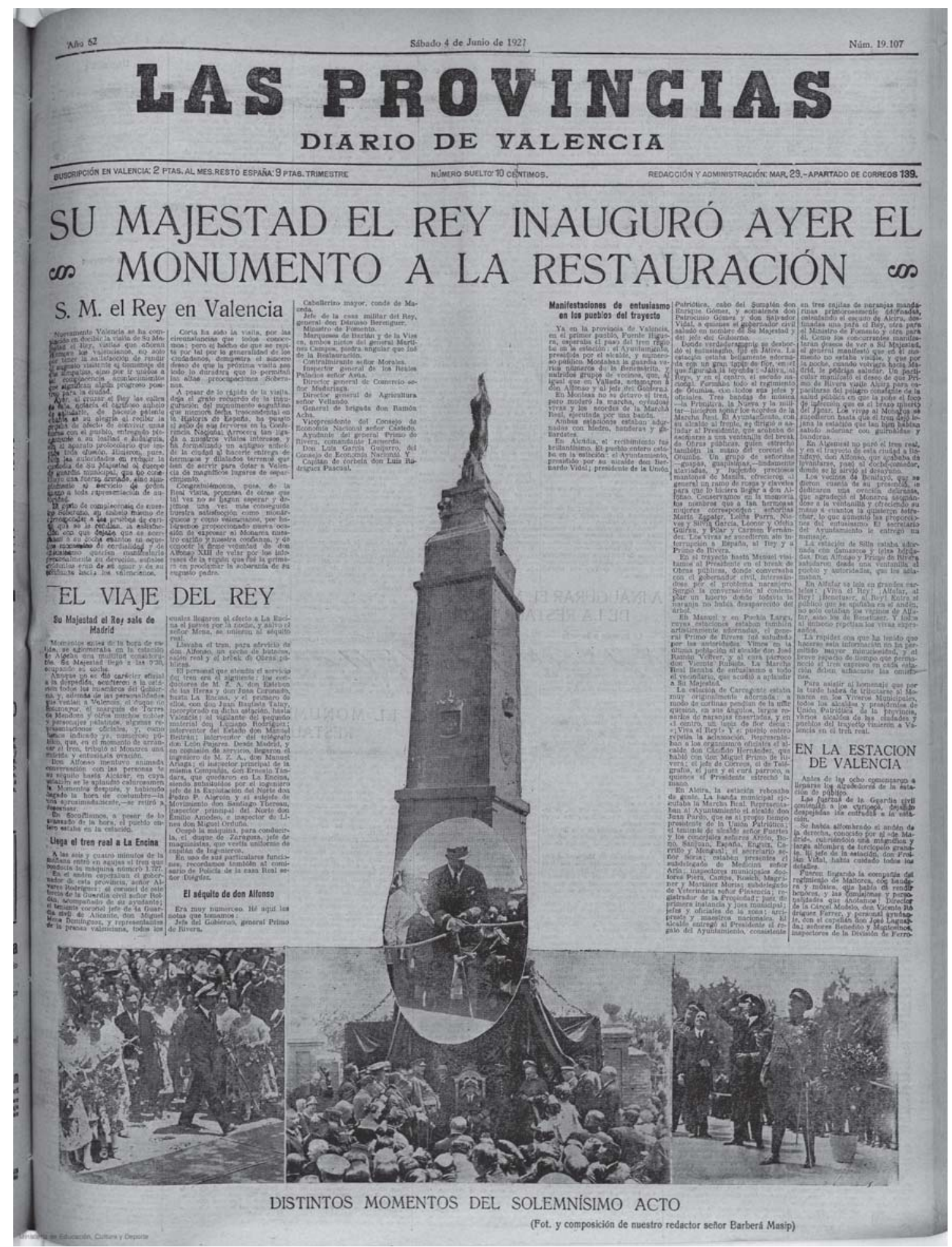

Ilustración 13. Portada del diario valenciano Las Provincias (4-6-1927) informando sobre la inauguración oficial en Sagunto del Monumento a la Restauración. Este monumento fue víctima de la iconoclasia antimonárquica durante la Segunda República española y sería finalmente demolido en la Guerra Civil. 


\section{BIBLIOGRAFÍA}

Antonio Annino y Francisco-Xavier Guerra (coords.), Inventando la nación. Iberoamérica. Siglo XIX, Fondo de Cultura Económica, México, 2003.

Maurice Agulhon, Marianne au pouvoir. L'imagerie et la symbolique républicaines de 1880 à 1914, Flammarion, París, 1989.

Roberto L. Blanco Valdés, La construcción de la libertad. Apuntes para una historia del constitucionalismo europeo, Alianza Editorial, Madrid, 2010.

Catherine Brice, Monumentalité publique et politique à Rome. Le Vittoriano, École Française de Rome, Roma, 1998.

Catherine Brice, Monarchie et identité nationale en Italie (1861-1900), Éditions de l'École des hautes études en scieces sociales, París, 2010.

Catherine Brice, "La monarchia e la nazionalizzazione degli italiani (1861-1900)", Memoria e ricerca. Rivista di storia contemporanea, n 42, 2013, pp. 69-86.

Concorso pel monumento al Re Vittorio Emanuele II da erigirsi in Roma a norma del programa. Pubblicato nella Gazzetta Ufficiale del 23 e 27 Settembre 1880, Tipografia di Mario Armanni, Roma, 1881.

Christian Demange, El Dos de Mayo. Mito y fiesta nacional (1808-1958), Marcial Pons / Centro de Estudios Políticos y Constitucionales, Madrid, 2004.

Descrizione del concetto espresso nel bozzetto contrassegnato col motto una pagina di storia presentato a concorso per la erezione di un monumento alla gloriosa memoria del Re Vittorio Emanuele in Roma, Tipografia Barbèra, Roma, 1881.

Javier Fernández Sebastián y Juan Francisco Fuentes Aragonés (dirs.), Diccionario politico y social del siglo XIX español, Alianza Editorial, Madrid, 2002.

Rafael Fernández-Sirvent, "De Rey soldado a Pacificador. Representaciones simbólicas de Alfonso XII de Borbón”, Historia Constitucional, n 11, 2010, pp. 4775.

Rafael Fernández-Sirvent, "Alfonso XII, el rey del orden y la concordia”, en Emilio La Parra (coord.), La imagen del poder. Reyes y regentes en la España del siglo XIX, Sintesis, Madrid, 2011, pp. 335-388.

Rafael Fernández-Sirvent, Las grandes revoluciones: independencia y libertad. Claves para una historia comparada, Paraninfo Universidad, Madrid, 2018.

Ivana Frasquet y Andréa Sleiman (eds.), De las independencias iberoamericanas a los estados nacionales (1810-1850). 200 años de historia, Iberoamericana Vervuert, Madrid, 2009.

Dario Gamboni, La destrucción del arte. Iconoclasia y vandalismo desde la Revolución Francesa, Cátedra, Madrid, 2014.

Manuel Girona Rubio, "El monumento de Sagunto a la Restauración de la monarquía borbónica”, Braçal, n 37, 2008, pp. 81-110. 
José Grases i Riera, Memoria del anteproyecto de monumento que ha de erigirse en Madrid a la gloria del Rey Don Alfonso XII, el Pacificador. Lema "María Cristina", M. Romero impresor, Madrid, 1901.

José Grases i Riera, Memoria del monumento que se erige en Madrid a la Patria española personificada en el rey Don Alfonso XII, M. Romero impresor, Madrid, 1902.

Jesús Gutiérrez Burón, El monumento de Alfonso XII en el parque del Retiro, Ayuntamiento de Madrid, Madrid, 1998.

Rodrigo Gutiérrez Viñuales, Monumento conmemorativo y espacio público en Iberoamérica, Cátedra, Madrid, 2004.

Morgan C. Hall, "El rey imaginado: la construcción politica de la imagen de Alfonso XIIP', en Javier Moreno Luzón (coord.), Alfonso XIII. Un político en el trono, Marcial Pons, Madrid, 2003, pp. 59-82.

Emilio La Parra (coord.), La imagen del poder. Reyes y regentes en la España del siglo XIX, Síntesis, Madrid, 2011.

Umberto Levra, Fare gli italiani. Memoria e celebrazione del Risorgimento, Comitato di Torino dell'Istituto per la storia del Risorgimento italiano, Torino, 1992.

Dieter Langewiesche, La época del Estado-nación en Europa, traducción al castellano de Jesús Millán, Publicacions de la Universitat de València, Valencia, 2012.

Stéphane Michonneau, Barcelona: memòria $i$ identitat. Monuments, commemoracions i mites, Eumo Editorial, Vic, 2002.

Jesús Millán y María Cruz Romeo, "Modelos de monarquía en el proceso de afirmación nacional de España, 1808-1923", Diacronie. Studi di Storia Contemporanea, $\mathrm{n}^{\mathrm{o}}$ 16, 4, 2013.

Monumento a S. M. el Rey D. Alfonso XII. Memoria sobre el estado de las obras en febrero de 1916, Establecimiento tipográfico de Jaime Ratés, Madrid, 1916.

Monumento a S. M. el Rey D. Alfonso XII. Memoria sobre el estado de las obras en diciembre de 1918, Establecimiento tipográfico de Jaime Ratés, Madrid, 1919.

Monumento a S. M. el Rey D. Alfonso XII. Memoria sobre el estado de las obras en diciembre de 1920, Imprenta de Ramona Velasco, Madrid, 1921.

Monumento a S. M. el Rey Don Alfonso XII. Memoria, 1901-1922, Imprenta de Ramona Velasco, Madrid, 1922.

Javier Moreno Luzón, “¿El rey de todos los españoles? Monarquía y nación”, en Javier Moreno Luzón y Xosé M. Núñez Seixas (eds.), Ser españoles. Imaginarios nacionalistas en el siglo XX, RBA, Barcelona, 2013.

Javier Moreno Luzón, "Monarchia in scena e discorsi nazionalisti nella Spagna del Rigenerazionismo (1902-1913)", Memoria e ricerca. Rivista di storia contemporanea, $\mathrm{n}^{\circ} 42,2013$, pp. 87-106.

Javier Moreno Luzón, "Alfonso el Regenerador. Monarquía escénica e imaginario nacionalista, en perspectiva comparada (1902-1913)", Hispania, n²44, 2013, pp. 319-348. 
Mónica Moreno Seco, "María Cristina de Habsburgo, la (in)discreta regente", en Emilio La Parra (coord.), La imagen del poder. Reyes y regentes en la España del siglo XIX, Sintesis, Madrid, 2011, pp. 389-430.

George L. Mosse, La nacionalización de las masas. Simbolismo politico y movimientos de masas en Alemania desde las Guerras Napoleónicas al Tercer Reich, Marcial Pons, Madrid, 2005.

Pierre Nora, Présent, nation, mémoire, Gallimard, París, 2011.

Andrzej Olechnowicz, "Il Regno Unito e la sua monarchia (1837-1914)", Memoria e ricerca. Rivista di storia contemporanea, $n^{\circ} 42,2013$, pp. 15-50.

Marie-Angèle Orobon, "La carne de la politica: ruptura democrática y simbología", Ayer. Revista de Historia Contemporánea, nº 112, 2018, pp. 73-98.

Marie-Angèle Orobon y José Luis González Fernández, "Echar a la calle: el destronamiento simbólico de Alfonso XIII”, Historia Constitucional, n 20, 2019.

Jaan van Osta, "The Emperor's New Clothes. The Reappearance of the Performing Monarchy in Europe, c. 1870-1914", en Jeroen Deploige y Gita Deneckere (eds.), Mystifying the Monarch. Studies on Discourse, Power, and History, Amsterdam University Press, Amsterdam, 2006, pp. 181-192.

Ignacio Peiró Martín, En los altares de la patria. La construcción de la cultura nacional española, Akal, Madrid, 2017.

Nikolaus Pevsner, Historia de las tipologías arquitectónicas, Ed. Gustavo Gili, Barcelona, 1979.

Progetto del monumento da erigersi in Roma al primo Re d'Italia Vittorio Emanuele II, Stabilimento di Giuseppe Civelli, Firenze, 1882.

Carlos Reyero, La escultura conmemorativa en España. La edad de oro del monumento público, 1820-1914, Cátedra, Madrid, 1999.

María del Socorro Salvador, La escultura monumental en Madrid: calles, plazas y jardines públicos (1875-1936), Editorial Alpuerto, Madrid, 1990.

Volker Sellin, "Monarchia e Nazione in Germania dal 1848 al 1914", Memoria e ricerca. Rivista di storia contemporanea, $n^{\circ} 42,2013$, pp. 33-50.

Carlos Serrano, El nacimiento de Carmen. Simbolos, mitos y nación, Taurus, Madrid, 1999.

Johannes Sträter, "El recuerdo histórico y la construcción de significados politicos. El monumento al emperador Guillermo en la montaña de Kyffhäuser", Historia y Politica, no 1, 1999, pp. 83-106.

Bertrand Tillier, "La mort des statues. Imaginaires archä̈ques et usages politiques de l'iconoclasme", en Emmanuel Fureix (dir.), Iconoclasme et révolutions. De 1789 à nos jours, Éditions Champ Vallon, Ceyzérieu, 2014. Introducción de E. Fureix disponible en linea: https://www.amazon.fr/Iconoclasme-révolutions-1789-nosjours/dp/2876739836

Bruno Tobia, L’Altare della Patria, Il Mulino, Bologna, 1998. 
LA EDIFICACIÓN PÚBLICA DE LA MONARQUÍA NACIONAL...

Joaquín Varela Suanzes-Carpegna, "Algunas reflexiones metodológicas sobre la Historia Constitucional”, Historia Constitucional, nº 8, 2007.

Enviado el (Submission Date): 27/04/2019

Aceptado el (Acceptance Date): 12/05/2019 